\title{
A Longitudinal Analysis on the Duration of Utterance in a Conversational Turn and Turn-Switching Pause in Preschool Children who Stutter during Interactions with Their Mothers
}

\author{
Hyo Jung Kwak ${ }^{a}$, Hyun Sub Sim ${ }^{a}$, Soo Bok Lee ${ }^{b}$ \\ ${ }^{a}$ Department of Communication Disorders, Ewha Womans University, Seoul, Korea \\ ${ }^{b}$ Department of Speech-Language Therapy \& Aural Rehabilitation, Woosong University, Daejeon, Korea
}

Correspondence: Soo Bok Lee, $\mathrm{PhD}$

Department of Speech-Language Therapy \& Aural Rehabilitation, Woosong University, 171

Dongdaejeon-ro, Dong-gu, Daejeon 34606, Korea Tel: $+82-42-630-9222$

Fax: +82-42-630-9229

E-mail: sblee@wsu.ac.kr

Received: July 20, 2021

Revised: August 11, 2021

Accepted: August 18, 2021

This work was supported by the Ministry of Education of the Republic of Korea and the National Research Foundation of Korea (NRF2018S1A5A2A03036976).

This article is based on a part of the first author's Master thesis.

\begin{abstract}
Objectives: The purpose of this study was to investigate, longitudinally, the duration of utterance in a conversational turn, duration of turn-switching pause, and frequency of disfluency which young children who stutter (CWS) and children who do not stutter (CWNS) showed during interactions with their mothers. Methods: Subjects for this study consisted of 2-5 year old CWS (male 2 and female 4), an age-matched group of CWNS (male 3 and female 3), and their mothers. Frequencies of normal disfluency (ND) and abnormal disfluency (AD), and duration of utterance in a conversational turn and duration of turn-switching pause were measured two times (initial visit and 12 months later) over the course of one year. Results: At initial visit, a significant group difference was found in frequency of AD. However, no significant difference was observed in duration of utterance in a conversational turn and duration of turn-switching pause both between two parent groups and between two child groups at initial visit and 12 months later. In the CWS group, at initial visit, a positive correlation was found between frequency of $A D$ and mother's duration of utterance in a conversational turn. Frequency of $A D$ was negatively correlated with both duration of turn-switching pause of mothers and that of children. After 12 months, there was a negative correlation between frequency of $A D$ and mother's duration of utterance in a conversational turn. Conclusion: These findings suggest that the longitudinal study of individual characteristics of CWS - mothers interactions can help speech-language pathologists to identify the interactional factors related to the recovery or persistence of stuttering and to enhance the efficacy of parent - child interaction therapy for CWS.
\end{abstract}

Keywords: Preschool children, Stuttering, Longitudinal study, Interaction, Duration of utterance in a conversational turn, Duration of turn-switching pause
학령전 아동들은 신경학적, 생리학적, 정서적, 그리고 언어학적 으로 성숙되어 가는 과정에서 자연스럽게 비유창성을 보이는데, 이 러한 비유창성을 보이는 아동들 가운데 어떤 아동이 말더듬에서 회복될 것인가 아니면 지속적으로 말더듬을 보일 것인가를 예측하 는 것은 쉽지 않다(Lee, Kwak, Yun, Shin, \& Sim, 2020).

말더듬 발생 및 지속에는 아동의 유전적, 신체적 요인들과 환경 적 요인들이 복합적으로 기여하고 있는 것으로 알려져 있다(Gui- tar, 2013; Lee \& Sim, 2007; Manning, 2010). 특히, 중요한 환경적 요 인인 부모는 학령전 아동의 말.언어발달에 큰 영향을 주기 때문에 (Kim \& Shin, 2016; Manning, 2010; Park, Lee, \& Sim, 2015) 말더 듬아동을 평가할 때, 아동의 의사소통 행동뿐만 아니라 아동과 부 모가 어떻게 상호작용하는가를 평가하며(Ahn, Shin, Kim, \& Sim, 2009), 부모의 상호작용 패턴을 변화시키기 위한 간접치료가 실시 되고 있다(Lee, 2014). 
하지만 아동과 부모의 상호작용을 비교한 결과 말더듬아동 집단 과 일반아동 집단 사이에 차이가 없다고 보고한 선행연구도 있다. 예를 들면, 말 속도, 대화차례 심 시간, 끼어들기 등과 같은 시간적 요인에서 말더듬아동 부모와 일반아동 부모 간 차이가 없다고 하 였다(Kelly \& Conture, 1992; Zebrowski, 1991, 1995). 이러한 연구 결과는 상호작용에 영향을 줄 수 있는 변인이 적절히 통제되지 않 았기 때문에, 학령전 말더듬아동과 부모가 대화하면서 상호작용 할 때 시간적 요인이 아동의 유창성에 어떠한 영향을 주는지에 대 한 연구가 요구된다(Ratner, 2004).

말더듬 발생 및 지속과 관련 있는 아동의 환경적 요인과 유전적, 신체적 요인들은 상호작용하여 아동의 말더듬에 영향을 미치며, 요인들 간의 상호 영향력 정도는 아동의 발달과정에 따라 변화한 다(Smith \& Kelly, 1997). 또한 말더듬은 날마다, 상황마다, 중재 전 후에 따라 매우 다양하게 변하므로 아동의 유창성 수행력을 정확 하게 파악하는 것은 어렵다(Lee, Park, \& Sim, 2019; Ok \& Rhee, 2003). 이러한 맥락에서 최근 Lee 등(2019)의 연구는 발화를 일회성 이 아닌 지속적으로 수집 및 분석하는 종단적 분석을 통해 말더듬 의 발달과 여러 요인들과의 관련성에 대해 설명하고자 하였다.

말더듬의 회복 및 지속과 관련이 있는 요인들에 관한 선행연구 들은 말더듬아동의 비유창성 빈도 및 유형(Sawyer \& Yairi, 2010; Throneburg \& Yairi, 2001; Yairi \& Ambrose, 1999), 심리적 측면(기 질, 성격 등(Kefalianos, Onslow, Ukoumunne, Block, \& Reilly, 2017a; Kefalianos et al., 2017b; Smith et al., 2017), 아동 또는 부모 의 말.언어적 측면(언어발달(Kloth, Janssen, Kraaimaat, \& Brutten, 1998; Kloth, Janssen, Kraaimaat, \& Brutten, 1999; Wagovich, Hall, \& Clifford, 2009; Watts, Eadie, Block, Mensah, \& Reilly, 2017), 조음 속도 및 음운능력(Hall, Amir, \& Yairi, 1999; Paden, Ambrose, \& Yairi, 2002; Usler, Smith, \& Weber, 2017) 등을 살펴보 았다. 그러나 아동. 부모의 상호작용 상황에서 아동과 부모 모두의 말.언어적 특성을 종단적으로 살펴본 연구는 소수에 불과하다

(Kloth et al., 1998, 1999; Lee \& Sim, 2016; Wagovich et al., 2009).

예를 들면, Kloth 등(1999)은 6년간의 종단연구를 통해 말더듬 아동. 부모 집단 23 쌍을 부모 보고에 따라 말더듬 지속집단과 회복 집단으로 분류하였다. 이후 1 개월과 12 개월 시점에 부모의 조음 속 도, 언어 복잡성, 의사소통 스타일과 아동의 수용 및 표현언어, 평균 발화 길이, 조음 속도를 측정하였다. 연구결과, 그룹 간 비교 시, 지 속집단 아동의 조음 속도가 회복집단 아동보다 변이성이 큰 것으 로 나타났고, 지속집단 어머니의 언어 복잡성이 회복집단 어머니보 다 유의하게 높은 것으로 나타났으며, 다른 요인에서는 차이가 없 었다. 시점 간 비교 시, 12 개월 시점에서 지속집단 아동의 조음 속도
가 일반아동보다 빨라지는 것으로 나타났다. 그러나 이 연구에서 는 종속변인으로 아동의 비유창성 변화를 살펴보지 않았기에, 아 동 및 부모 요인과 아동 비유창성 간의 관련성을 알 수 없다.

Lee와 Sim (2016)은 2세 6개월-5세 4개월 말더듬아동. 부모 집 단 18 쌍을 대상으로 12 주간 상호작용 치료를 실시한 후, 말더듬 지 속집단과 회복집단으로 분류하였다. 이후 3 개월과 6 개월 시점에 부 모의 발화 길이, 대화차례 쉼 시간, 조음 속도, 의사소통 행동(질문 하기, 지시/간섭하기)과 아동의 발화 길이, 조음 속도가 아동의 $\mathrm{AD}$ (abnormal disfluency) 빈도와 상관이 있는지, 그리고 아동의 $\mathrm{AD}$ 빈도 감소를 예측할 수 있는 변인이 무엇인지 살펴보았다. 연구결 과, 3 개월 시점에는 부모 요인(발화 길이, 대화차례 쉼 시간, 조음 속 도, 지시/간섭 변화)이, 6 개월 시점에는 아동의 발화 길이와 부모의 질문하기 행동이 아동의 $\mathrm{AD}$ 빈도 변화에 영향을 준 것으로 나타 났다. 이러한 결과는 환경적 요인 중 하나인 '부모'가 아동과 상호작 용할 때 보이는 특성에 따라 아동의 말더듬 빈도가 달라질 수 있으 며, 말더듬 평가 및 중재 시, 상호작용 특성을 면밀하게 살피어 변화 시켜야 할 요인들을 찾아내는 것이 중요함을 시사한다. 또한 부모 뿐만 아니라 아동의 요인에 따라 비유창성 변화가 나타날 수 있으 므로 부모와 아동 요인 모두 살펴볼 필요가 있다. 그러나 이 연구에 서는 중재를 통해 부모의 상호작용 행동을 변화시킨 후, 이러한 변 화로 인해 아동의 비유창성이 어떻게 변화하는지 살펴보았기에, 아동과 부모가 일상에서 상호작용할 때 나타나는 아동과 부모의 요인을 반영한다고 보기는 어렵다. 따라서 아동. 부모 상호작용 시 나타나는 요인들과 아동의 비유창성 간 관계를 정확하게 파악하기 위해서는 자연스러운 상호작용 상황에서 상호작용 특성을 종단적 으로 확인하는 것이 필요하다. 이에 본 연구에서는 아동과 부모가 일상에서 자연스럽게 대화하면서 상호작용할 때 나타나는 아동의 비유창성 빈도와 아동과 부모의 상호작용 특성을 종단적으로 살 펴보고자하였다.

대화(conversation)는 두 사람 이상의 대화 참여자가 공통의 화 제로 말을 주고받는 쌍방향적 의사소통 과정으로, 자연스러운 대 화 상황에서는 화자와 청자의 역할이 바뀌면서 순차적으로 대화차 례(turn-taking)가 일어나게 된다(Heo \& Lee, 2012). 대화차례는 대 화 상대자가 발화를 시작하기 전까지 현재 화자가 산출한 발화 (Savelkoul, Zebrowski, Feldstein, \& Cole-Harding, 2007)로, 청자 와 화자의 상호작용을 구성하는 요소이며, 대화를 구성하는 기본 적인 기술이라고 할 수 있다(Choi \& Lee, 2013). 대화차례의 특성을 밝히기 위한 측정치로는 대화차례 발화 시간과 대화차례 쉼 시간 이 사용된다. 대화차례 발화 시간은 현재 화자가 본인의 대화차례 동안 말을 하기 위해 사용한 시간, 즉 발화 시간을 의미하며, 대화 
차례 쉼 시간은 현재 화자의 발화가 종료되는 시점부터 대화 상대 자의 발화가 시작되는 지점까지의 쉼 시간을 의미한다. 대화 참여 자들은 대화를 하며 상호작용할 때 본인의 대화차례에서 발화 시 간의 길이를 적절하게 유지하여야 하며, 서로의 발화를 방해하지 않고 충분히 발화할 수 있도록 적절한 대화차례 쉼 시간을 가져야 한다(Owens, 2004; Park \& Choi, 2019).

대화차례 발화 시간은 대화의 독점 또는 경쟁 여부를 판단할 수 있는 측정치이다. 즉, 부모와 아동의 대화차례 발화 시간이 비슷할 경우, 아동 부모 상호작용 시 두 사람의 대화차례가 1:1로 균형을 이루고 있다고 볼 수 있다. 반면, 부모의 대화차례 발화 시간이 아동 의 대화차례 발화 시간보다 길 경우, 아동과 부모의 대화차례가 불 균형을 이루게 되고, 이는 아동이 대화차례를 얻기 위해 부모와 경 쟁하게 만들 수 있다(Manning, 2010; Winslow \& Guitar, 1994). 하 지만 대화차례 발화 시간은 상호작용 시 대화 상대자의 행동에 영 향을 받는다. Savelkoul 등(2007)의 연구에 의하면 한 대화 참여자 의 행동 변화는 다른 대화 참여자의 행동을 같은 방향으로 변화시 킬 수 있다고 보는데, 이러한 관점에 따르면 부모의 대화차례에서 발화 시간이 길어지면, 아동도 본인의 대화차례에서 긴 발화 시간 을 보일 수 있다. 이러한 양상은 인지적, 언어적, 운동적, 정서적 용 량이 아직 충분히 발달하지 않은 아동에게 부담감을 느끼게 할 수 있고 비유창성이 나타나게 만들 수 있으며, 이러한 상황이 지속될 경우 말더듬으로 발전할 수 있다(Kim \& Sim, 2021).

대화차례 쉼 시간의 경우, 부모의 쉼 시간이 짧으면 아동은 빠르 게 대답해야 한다는 압박을 느끼게 된다(Manning, 2010). 압박을 느낀 아동은 대화차례 쉼 시간 단축, 끼어들기, 대화차례 발화 시간 연장과 같은 의사소통 전략들을 자주 사용하게 된다. 이러한 아동 의 대응전략들은 아동이 발화를 계획하고 산출하는 말운동 시스 템에 과부하를 초래하여 말더듬 행동이 나타나게 하거나 악화시키 는 결과를 초래할 수 있다(Conture, 1990; Savelkoul et al., 2007).

하지만 이러한 상호작용의 시간적 요인들이 아동의 말더듬 발생 및 지속과 관련이 있는 것으로 보이나, 구체적으로 어떠한 영향을 주는지 아직까지 명확하게 밝혀져 있지 않으며(Lee \& Sim, 2016), 현재 대화차례 발화 시간을 종단적으로 측정한 연구는 없는 실정 이다. 대화차례 쉼 시간도 연구자 및 부모의 요인을 통제한 실험적 인 상황에서 살펴보았기 때문에(Ahn et al., 2009; Ratner, 1992; Lee \& Sim, 2016; Newman \& Smith, 1989), 아동과 부모가 일상에서 상 호작용할 때 나타나는 아동과 부모의 시간적 특성을 반영한다고 보기 어렵다.

따라서 본 연구는 학령전 말더듬아동과 어머니가 일상에서 대 화하면서 상호작용할 때 나타나는 대화차례 발화 시간과 대화차례
쉼 시간이 아동의 비유창성과 어떠한 관련이 있는가를 12 개월간 종단적으로 분석하였다. 아울러 과연 말더듬아동과 어머니의 상호 작용 특성이 일반아동 집단과 비교했을 때 차이를 보이는가를 살 펴보았다.

\section{연구방법}

\section{연구대상}

본 연구는 초기 말.언어평가 시 만 2-5세 말더듬아동 6명(남자:2 명, 여자: 4 명)과 아동의 어머니 6명, 일반아동 6명(남자: 3 명, 여자: 3 명)과 아동의 어머니 6 명, 총 12 쌍을 대상으로 하였다. 대상자들은 본 연구에 대한 상세한 안내를 충분히 듣고 서면으로 연구 참여에 동의하였다. 본 연구는 우송대학교 기관생명연구윤리심의위원회 (IRB)의 승인을 받아 진행되었다(1041549-210413-SB-120).

대상자 선정 기준은 다음과 같다. 말더듬아동은 (1) 부모 또는 보 건복지부 언어재활사 자격증을 소지한 언어재활사에 의해 말더듬 으로 평가되었으며, (2) 파라다이스-유창성검사 II (Paradise-Fluency Assessment II, P-FA II; Sim, Shin, \& Lee, 2010) 결과, 중증도 가 약함이거나 중간인 말더듬으로 진단되고, (3) 수용·표현어휘력 검사(Receptive \& Expressive Vocabulary Test, REVT; Kim, Hong, Kim, Jang, \& Lee, 2009) 실시 결과, 백분위 점수가 -1 표준편차 이 상에 속하며, (4) 우리말 조음·음운검사(Urimal Test of Articulation an Phonology, U-TAP; Kim \& Shin, 2004) 실시 결과, 낱말수 준에서의 자음정확도가 정상범위에 속하고, (5) 기타 동반장애가 없는 아동을 대상으로 하였다. 연구윤리에 따라 말더듬 치료 여부 는 말더듬아동 대상자 선정 기준에 포함하지 못하였고, 본 연구에 선정된 대상 아동 중, 2 명은 평가 후 연구기간 동안 간접치료와 직접 치료를 1 년 동안 받았고, 3 명은 간접치료를 3 개월 동안 받았으며, 1 명은 치료를 받지 않았다.

일반아동은 말더듬아동과 생활연령 및 언어연령이 일치하는 아 동으로 선정하였다. (1) 부모가 말더듬 문제가 없는 것으로 보고하 며, (2) P-FA II 결과, 정상적 비유창성으로 나타나고, (3) REVT 실 시 결과, 백분위 점수가 - 1 표준편차 이상에 속하며, (4) U-TAP 실 시 결과, 낱말수준에서의 자음정확도가 정상범위에 속하고, (5) 기 타 동반장애가 없는 아동을 대상으로 하였다. 연구 참여 아동들에 대한 구체적인 정보는 Table 1과 같다.

집단 간 동일성 검정을 위한 맨-휘트니 U-검정(Mann-Whitney U-test) 비모수 검정 결과, 생활연령, 수용 및 표현어휘 점수, 낱말수 준에서의 자음정확도에서 집단 간에 통계적으로 유의한 차이를 보 이지 않았다( $p>.05)$. 
Table 1. Participant's characteristics

\begin{tabular}{|c|c|c|c|c|c|c|c|}
\hline Group & Case no. & Gender & Age at initial visit & Age at onset & Duration of treatment & $\begin{array}{l}\text { Treatment type at } \\
\text { initial visit }\end{array}$ & $\begin{array}{c}\text { Stuttering severity at } \\
\text { initial visit }\end{array}$ \\
\hline \multirow[t]{6}{*}{ CWS $(N=6)$} & CWS1 & $\mathrm{F}$ & $2 ; 1$ & $1 ; 10$ & 3 months & Indirect treatment & NT \\
\hline & CWS2 & $\mathrm{F}$ & $2 ; 10$ & $1 ; 11$ & 3 months & Indirect treatment & moderate \\
\hline & CWS3 & $\mathrm{F}$ & $3 ; 4$ & $2 ; 5$ & 12 months & Indirect, Direct treatment & moderate \\
\hline & CWS4 & $M$ & $3 ; 9$ & $3 ; 5$ & 12 months & Indirect, Direct treatment & moderate \\
\hline & CWS5 & M & $4 ; 9$ & $3 ; 3$ & 3 months & Indirect treatment & moderate \\
\hline & CWS6 & $\mathrm{F}$ & $5 ; 7$ & $5 ; 0$ & No & No & mild \\
\hline \multirow[t]{6}{*}{ CWNS $(\mathrm{N}=6)$} & CWNS1 & M & $2 ; 3$ & - & - & - & - \\
\hline & CWNS2 & $\mathrm{F}$ & $2 ; 7$ & - & - & - & - \\
\hline & CWNS3 & M & $3 ; 11$ & - & - & - & - \\
\hline & CWNS4 & $M$ & $4 ; 10$ & - & - & - & - \\
\hline & CWNS5 & $\mathrm{F}$ & $4 ; 11$ & - & - & - & - \\
\hline & CWNS6 & $\mathrm{F}$ & $5 ; 4$ & - & - & - & - \\
\hline
\end{tabular}

CWS = children who stutter; CWNS = children who do not stutter; NT = Not rated.

\section{연구절차}

대상자 선정 기준을 충족한 말더듬아동-어머니, 일반아동.어머 니들을 대상으로 연구자가 아동의 가정 또는 어린이집/유치원에 방문하여 아동과 어머니에게 약 20-30분 동안 상호작용 놀이를 진 행하게 하여 총 두 차례(평가 시점, 평가 후 12 개월 시점) 아동의 100 발화와 아동의 발화에 포함된 어머니 발화를 녹화 수집하였다.

상호작용 놀이는 조용한 방에서 진행되었으며, 아동이 평소에 가 지고 노는 '찰흙놀이', '블록놀이' 등의 장난감을 활용하고, 자연스 러운 놀이 상황이 되도록 하기 위해 어머니에게 '평소와 같이 아동 과 대화하고 놀아주세요.'라는 최소한의 지시만 주고 진행하게 하 였다.

\section{자료분석}

\section{발화 구분 및 선택}

상호작용 놀이를 통해 수집된 발화 자료 중, 아동의 첫 5 발화를 제외하고 순서대로 100 발화와 아동의 100 발화에 포함된 어머니의 발화를 전사하였다. 그리고 $\operatorname{Kim}$ (2014)의 분석 기준을 참고하여 발 화를 구분 및 선택하였다. 발화 구분 및 선택 기준은 Appendix 1에 제시하였다.

\section{아동의 $\mathrm{ND}$ 와 $\mathrm{AD}$ 빈도 분석}

아동의 100 발화에 포함된 normal disfluency (ND)와 AD 빈도 를 분석하였다. $\mathrm{ND}$ 와 $\mathrm{AD}$ 유형은 P-FA II의 비유창성 분류 기준에 따라 측정하였다. 만약 한 단어에서 두 개의 $\mathrm{ND}$ 또는 $\mathrm{AD}$ 유형이 동반되어 나타나는 경우는(예: 막힘을 동반한 반복2) 2개의 ND 또 는 $\mathrm{AD}$ 유형으로 계산하였다(Ambrose \& Yairi, 1999).

\section{아동과 어머니의 대화차례 발화 시간 및 대화차례 쉼 시간 분석}

아동의 100 발화와 아동의 100 발화에 포함된 어머니의 발화에서 나타난 아동과 어머니의 대화차례 발화 시간과 대화차례 심 시간 을 측정하기 위하여 각 아동.어머니의 상호작용 놀이를 녹화한 영 상을 Goldwave 5.70 (Chon \& Lee, 2016)을 사용하여 .wav 형식의 오디오 파일로 변환하였다(sampling rate: $44 \mathrm{kHz}, \mathrm{mono})$. 그리고 Praat 5.4.18 (Boersma \& Weenink, 2015)을 사용하여 시간을 측정 하였다.

대화차례 발화 시간은 아동과 어머니의 대화차례 발화 시간을 측정하였으며, 아동의 대화차례 발화 시간은 아동의 대화차례에서 나타난 아동의 총 발화 길이를, 어머니의 대화차례 발화 시간은 어 머니의 대화차례에서 나타난 어머니의 총 발화 길이를 의미한다. Chon, Sawyer와 Ambrose (2012)의 연구에서 조음 속도를 분석하 기 위해 발화 시간을 측정한 방법에 따라 Figure 1과 같이 화자의 대화차례에서 발화 파형이 시작되는 지점부터 종료되는 지점까지 의 시간을 측정하고, 하나의 대화차례에서 두 개 이상의 발화가 나 타난 경우에는 각 발화 파형의 시간을 더하여 계산하였다. 아동과 어머니의 발화가 일부 또는 전체 중첩된 경우, 파형을 통한 분석이 어려우므로 이러한 경우, 대화차례 발화 시간 분석에서 제외하였 다. 또한 비유창성 지속시간과 0.25 초 이상의 쉼 지속시간은 제외하 였다. 비유창성 지속시간의 경우, 반복1, 반복2는 반복단위와 반복 단위 사이의 쉼 지속시간을, 간투사, 연장은 비유창한 소리가 시작 되는 지점부터 끝나는 지점까지의 지속시간을, 막힘은 부자연스럽 고 불수의적인 주저(unnatural and forced hesitation)가 시작되는 지점부터 끝나는 지점까지의 지속시간을 측정하였다(Chon et al., 2012). 아동의 100 발화에서 나타난 아동의 대화차례 발화 시간을 측정한 후, 전체 대화차례 발화 시간을 더하고 아동의 대화차례 빈 

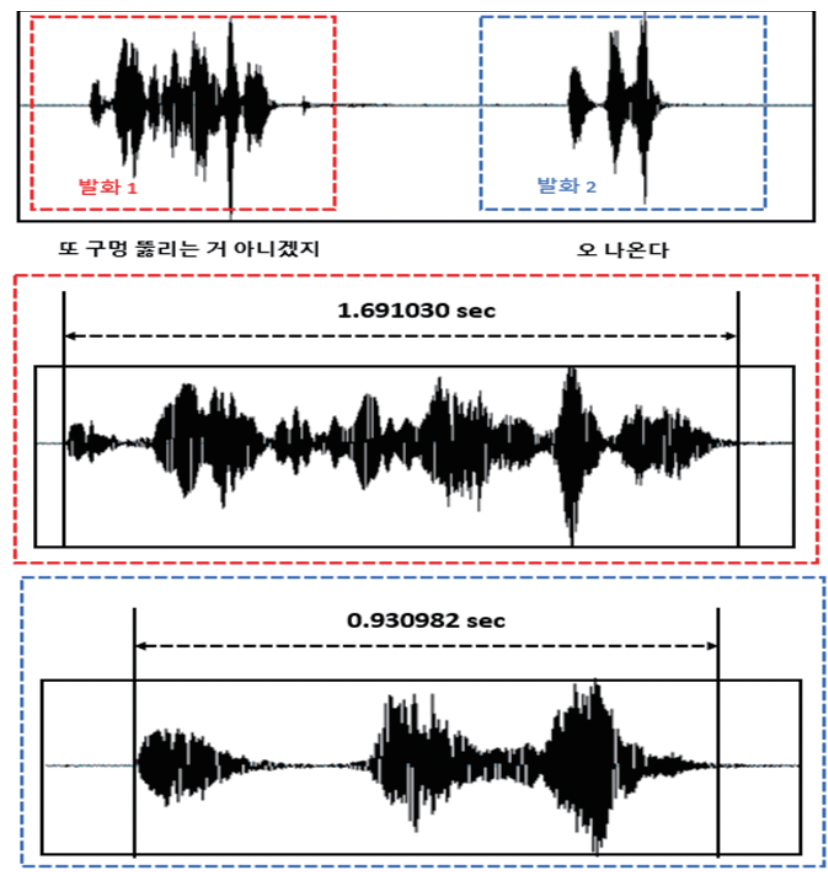

대화차례 발화 시간(sec)

: 발화 1 지속시간 1.691030 + 발화 2 지속시간 $0.930982=2.622012$

Figure 1. Duration of utterance in a conversational turn.

도로 나누어 아동의 평균 대화차례 발화 시간을 구하였다. 동일한 방식으로 어머니의 평균 대화차례 발화 시간도 구하였다.

대화차례 쉼 시간은 아동과 어머니의 대화차례 쉼 시간을 측정 하였으며, 아동의 대화차례 쉼 시간은 어머니의 대화차례가 끝나는 지점부터 아동의 대화차례가 시작되는 지점까지의 심 길이를, 어머 니의 대화차례 쉼 시간은 아동의 대화차례가 끝나는 지점부터 어 머니의 대화차례가 시작되는 지점까지의 쉼 길이를 의미한다. Figure 2 와 같이 현재 화자의 대화차례가 끝나는 지점부터 대화 상대 자의 대화차례가 시작되는 지점까지의 시간을 측정하였다(Kelly, 1994; Lee, 2014).

아동의 100 발화에서 나타난 아동의 대화차례 쉼 시간을 측정한 후, 전체 대화차례 쉼 시간을 더하고 아동의 대화차례 빈도로 나누 어 아동의 평균 대화차례 쉼 시간을 구하였다. 동일한 방식으로 어 머니의 평균 대화차례 심 시간도 구하였다.

\section{평가자 간 신뢰도}

전체 자료의 $20 \%$ 에 해당하는 4 명의 자료를 유창성장애 평가 및 치료 경험이 있는 언어재활사 1 급, 2 급 자격증 소지자 2 명과 본 연구 자가 독립적으로 전사하고 아동의 $\mathrm{ND}$ 및 $\mathrm{AD}$ 빈도, 아동과 어머니 의 대화차례 발화 시간 및 대화차례 쉼 시간을 분석하여 신뢰도를

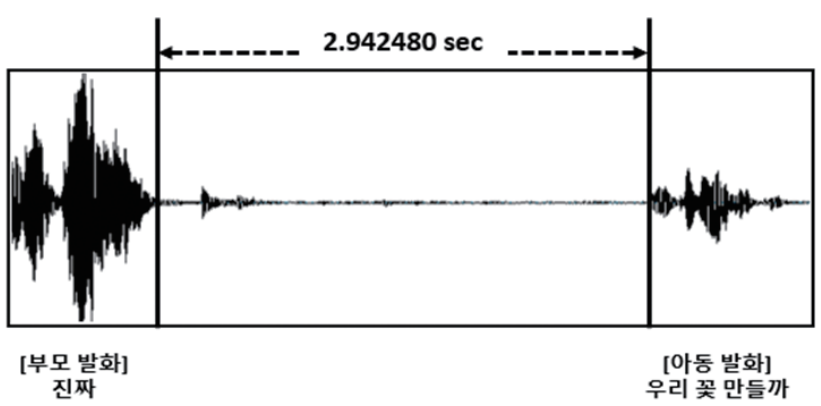

Figure 2. duration of turn-switching pause calculation.

산출하였다.

$\mathrm{ND}$ 빈도의 신뢰도 산출 공식은 다음과 같다.

평가자 간 신뢰도 $(\%)=($ 일치한 $\mathrm{ND}$ 빈도/발화에서 나타난 $\mathrm{ND}$ 빈도 $)^{\star} 100$

나머지 요인들도 같은 공식을 적용하여 산출한 신뢰도는 아동의 $\mathrm{ND}$ 와 $\mathrm{AD}$ 빈도, 대화차례 발화 시간, 대화차례 심 시간은 각각 $93.5 \%, 92.1 \%, 89.9 \%, 87.5 \%$, 어머니의 대화차례 발화 시간, 대화차 례 쉼 시간은 각각 $89.6 \%, 88.6 \%$ 였다.

\section{통계처리}

본 연구에서는 IBM SPSS statistics 26.0 (IBM-SPSS Inc., Chicago, IL, USA)을 이용하여 자료를 분석하였다. 첫째, 각 시점(평가 시, 12 개월)에서 말더듬아동 집단과 일반아동 집단 간 $\mathrm{ND}$ 와 $\mathrm{AD}$ 빈도, 대화차례 발화 시간, 대화차례 심 시간이 유의한 차이가 있는 지, 말더듬아동 어머니 집단과 일반아동 어머니 집단 간 어머니의 대화차례 발화 시간, 대화차례 심 시간이 유의한 차이가 있는지 살 펴보기 위하여 맨-휘트니 U-검정(Mann-Whitney U-test)을 실시 하였다. 둘째, 각 집단(말더듬아동 집단, 일반아동 집단, 말더듬아 동 어머니 집단, 일반아동 어머니 집단)에서 시점(평가 시점, 평가 후 12 개월 시점) 간 차이가 있는지 살펴보기 위하여 윌콕슨 부호순위 검증(Wilcoxon Signed-Rank Test)을 실시하였다. 셋째, 각 시 점 및 각 집단(말더듬아동.어머니 집단, 일반아동 어머니. 집단)에 서 요인 간 상관관계를 살펴보기 위하여 스피어만 등위상관분석 (Spearman rank correlation)을 실시하였다. 결과 해석 시에는 50\% 이상을 설명할 수 있는 상관계수.70 이상을 통계적으로 의미 있는 수치로 설정하였다. 넷째, 개별 말더듬아동 및 어머니의 상호작용 특성 변화 양상이 어떠한지 살펴보기 위하여 질적 분석을 실시하 였다. 


\section{연구결과}

\section{아동의 비유창성 빈도}

각 시점(평가 시점, 평가 후 12 개월 시점)에서 말더듬아동 집단과 일반아동 집단의 $\mathrm{ND}$ 및 $\mathrm{AD}$ 빈도에 대해 비교한 결과는 Table 2와 같다. 각 시점에 나타난 아동의 $\mathrm{ND}$ 및 $\mathrm{AD}$ 빈도의 평균과 표준편 차는 Appendix 2와같다.

\section{집단 간 비유창성 빈도 비교}

각 시점에서 집단 간 $\mathrm{ND}$ 및 $\mathrm{AD}$ 빈도에 유의한 차이가 있는가를 알아보기 위해 Mann-Whitney U-Test를 실시한 결과, 평가 시점에 서 말더듬아동 집단의 $\mathrm{AD}$ 빈도가 일반아동 집단의 $\mathrm{AD}$ 빈도보다 통계적으로 유의하게 높은 것으로 나타났다 $(\mathrm{Z}=-2.892, p<.01)$.

\section{시점 간 비유창성 빈도 비교}

각 집단에서 시점 간 $\mathrm{ND}$ 및 $\mathrm{AD}$ 빈도에 유의한 차이가 있는가를 알아보기 위해 Wilcoxon Signed-Rank Test를 실시한 결과, 두 집단 모두 유의한 차이가 없는 것으로 나타났다(말더듬아동 집단의 $\mathrm{ND}$ 빈도: $\mathrm{Z}=-.318, p=.750$; 말더듬아동 집단의 $\mathrm{AD}$ 빈도: $\mathrm{Z}=$ $-.946, p=.344$; 일반아동 집단의 $\mathrm{ND}$ 빈도: $\mathrm{Z}=-1.472, p=.141$; 일 반아동 집단의 $\mathrm{AD}$ 빈도: $\mathrm{Z}=.000, p=1.000$ ).

\section{어머니의 대화차례 발화 시간과 대화차례 쉼 시간}

각 시점(평가 시점, 평가 후 12 개월 시점)에서 말더듬아동 어머니 집단과 일반아동 어머니 집단의 대화차례 발화 시간과 대화차례 심 시간에 대해 비교한 결과는 Table 3 과 같다. 각 시점에 나타난 어 머니의 대화차례 발화 시간과 대화차례 쉼 시간의 평균과 표준편 차는 Appendix 3과 같다.

집단 간 대화차례 발화 시간 및 대화차례 쉼 시간 비교

각 시점에서 집단 간 대화차례 발화 시간과 대화차례 쉼 시간에

Table 2. Comparisons of ND and AD frequency between children groups

\begin{tabular}{lcccc}
\hline Period & Disfluency type & CWS (N=6) & CWNS (N=6) & Z \\
\hline Initial visit & ND & $17.50(17.75)$ & $8.00(7.5)$ & -2.1 \\
\multirow{3}{*}{12 months later } & AD & $11.50(19.75)$ & $2.50(2.75)$ & $-2.892^{*}$ \\
& ND & $18.50(13.25)$ & $11.50(12.00)$ & -1.363 \\
& AD & $10.00(10.00)$ & $1.50(4.00)$ & -1.942 \\
\hline
\end{tabular}

Vales are presented as Median (Interquartile range).

$N D=$ normal disfluency; $A D=$ abnormal disfluency; $C W S=$ children who stutter; CWNS = children who do not stutter. ${ }^{*} p<.01$.
유의한 차이가 있는가를 알아보기 위해 Mann-Whitney U-Test를 실시한 결과, 통계적으로 유의한 차이가 없는 것으로 나타났다(평 가 시점에서 대화차례 발화 시간: $\mathrm{Z}=.000, p=1.000$; 평가 시점에서 대화차례 심 시간: $\mathrm{Z}=-.801, p=.423$; 평가 후 12 개월 시점에서 대화 차례 발화 시간: $\mathrm{Z}=-1.121, p=.262$; 평가 후 12 개월 시점에서 대화 차례 쉼 시간: $Z=-1.281, p=.200)$.

\section{시점 간 대화차례 발화 시간 및 대화차례 쉼 시간 비교}

각 집단에서 시점 간 대화차례 발화 시간과 대화차례 쉼 시간에 유의한 차이가 있는가를 알아보기 위해 Wilcoxon Signed-Rank Test를 실시한 결과, 말더듬아동 어머니 집단은 대화차례 발화 시 간과 쉼 시간 모두 통계적으로 유의한 차이가 없는 것으로 나타났 다(대화차례 발화 시간: $\mathrm{Z}=-.105, p=.917$; 대화차례 쉼 시간: $\mathrm{Z}=$ $-.943, p=.345)$. 일반아동 어머니 집단에서는 대화차례 발화 시간 이 평가 시점보다 12 개월 시점에서 유의하게 짧아지는 것으로 나타 났고, 대화차례 심 시간은 통계적으로 유의한 차이가 없는 것으로 나타났다(대화차례 발화 시간: $Z=-1.992, p<.05$; 대화차례 쉼 시 간: $\mathrm{Z}=-1.153, p=.249)$.

\section{아동의 대화차례 발화 시간과 대화차례 쉼 시간}

각 시점(평가 시점, 평가 후 12 개월 시점)에서 말더듬아동 집단과 일반아동 집단의 대화차례 발화 시간과 대화차례 쉼 시간에 대해 비교한 결과는 Table 4 와 같다. 각 시점에 나타난 아동의 대화차례 발화 시간과 대화차례 쉼 시간의 평균과 표준편차는 Appendix 4 와같다.

\section{집단 간 대화차례 발화 시간 및 대화차례 쉼 시간 비교}

각 시점에서 집단 간 대화차례 발화 시간과 대화차례 쉼 시간에 유의한 차이가 있는가를 알아보기 위해 Mann-Whitney U-Test를 실시한 결과, 통계적으로 유의한 차이가 없는 것으로 나타났다(평

Table 3. Comparison of duration of utterance in a conversational turn and duration of turn-switching pause between mother's groups

\begin{tabular}{|c|c|c|c|c|}
\hline Period & Duration type & CWS (N=6) & CWNS (N=6) & Z \\
\hline \multirow[t]{2}{*}{ Initial visit } & $\begin{array}{l}\text { Utterance in a conversational } \\
\text { turn (sec) }\end{array}$ & $2.94(.75)$ & $2.85(1.15)$ & 0 \\
\hline & Turn-switching pause (sec) & $.53(.16)$ & $.66(0.39)$ & -.801 \\
\hline \multirow[t]{2}{*}{$\begin{array}{l}12 \text { months } \\
\text { later }\end{array}$} & $\begin{array}{l}\text { Duration of utterance in a } \\
\text { conversational turn (sec) }\end{array}$ & $2.77(1.70)$ & $2.10(1.55)$ & -1.121 \\
\hline & Turn-switching pause (sec) & $.30(.57)$ & $.59(.50)$ & -1.281 \\
\hline
\end{tabular}

Vales are presented as Median (Interquartile range).

$\mathrm{ND}=$ normal disfluency; $\mathrm{AD}=$ abnormal disfluency; $\mathrm{CWS}=$ children who stutter; CWNS = children who do not stutter. 
Table 4. Comparison of duration of utterance in a conversational turn and duration of turn-switching pause between children groups

\begin{tabular}{|c|c|c|c|c|}
\hline Period & Duration type & CWS (N=6) & CWNS (N=6) & Z \\
\hline \multirow[t]{2}{*}{ Initial visit } & $\begin{array}{l}\text { Utterance in a conversational } \\
\text { turn (sec) }\end{array}$ & $2.38(1.37)$ & $2.27(.79)$ & -.320 \\
\hline & Turn-switching pause (sec) & $.8(.53)$ & $1.2(.89)$ & -1.761 \\
\hline \multirow[t]{2}{*}{$\begin{array}{l}12 \text { months } \\
\text { later }\end{array}$} & $\begin{array}{l}\text { Duration of utterance in a } \\
\text { conversational turn (sec) }\end{array}$ & $3.37(4.16)$ & $2.84(2.39)$ & 0 \\
\hline & Turn-switching pause (sec) & $.88(.44)$ & $.84(.63)$ & -.160 \\
\hline
\end{tabular}

Vales are presented as Median (Interquartile range).

$\mathrm{ND}=$ normal disfluency; $\mathrm{AD}=$ abnormal disfluency; $\mathrm{CWS}=$ children who stutter; CWNS = children who do not stutter.

가 시점에서 대화차례 발화 시간: $Z=-.320, p=.749$; 평가 시점에서 대화차례 심 시간: $\mathrm{Z}=-1.761, p=.078$; 평가 후 12 개월 시점에서 대 화차례 발화 시간: $\mathrm{Z}=.000, p=1.000$; 평가 후 12 개월 시점에서 대 화차례 쉼 시간: $\mathrm{Z}=-.160, p=.873)$.

\section{시점 간 대화차례 발화 시간 및 대화차례 쉼 시간 비교}

각 집단에서 시점 간 대화차례 발화 시간과 대화차례 심 시간에 유의한 차이가 있는가를 알아보기 위해 Wilcoxon Signed-Rank Test를 실시한 결과, 두 집단 모두 시점 간 유의한 차이가 없는 것으 로 나타났다(말더듬아동 집단의 대화차례 발화 시간: $\mathrm{Z}=-.943$, $p=.345$; 말더듬아동 집단의 대화차례 쉼 시간: $\mathrm{Z}=-.943, p=.345$; 일반아동 집단의 대화차례 발화 시간: $\mathrm{Z}=-1.572, p=.116$; 일반아 동 집단의 대화차례 쉼 시간: $\mathrm{Z}=-.943, p=.345$ ).

\section{아동 및 어머니 요인과 아동의 비유창성 빈도 간의 관계}

평가 시점과 평가 후 12 개월 시점에 말더듬아동 집단과 일반아 동 집단의 $\mathrm{ND}$ 및 $\mathrm{AD}$ 빈도와 아동 요인(대화차례 발화 시간, 대화 차례 쉼 시간), 어머니 요인(대화차례 발화 시간, 대화차례 쉼 시간) 간의 상관관계를 살펴보기 위해 스피어만 등위상관분석을 실시하 였다. 상관관계 분석에서의 통계적 해석 기준은 변수 간 전체 분산 의 $50 \%$ 이상의 설명력을 가지는 상관계수. 70 이상으로 하였다.

\section{평가 시점의 상관 분석}

평가 시점의 말더듬아동 집단과 일반아동 집단의 $\mathrm{ND}$ 및 $\mathrm{AD}$ 빈 도와 아동 요인, 어머니 요인 간의 관계를 스피어만 등위상관분석 한 결과는 Appendix 5 와 같다.

말더듬아동 - 어머니 집단에서 아동 $\mathrm{AD}$ 빈도는 어머니 대화차례 발화 시간 $(\mathrm{r}=.754, p=.084)$ 과 정적상관관계를 보였고, 아동 대화 차례 쉼 $(\mathrm{r}=-.754, p=.084)$, 어머니 대화차례 쉼 $(\mathrm{r}=-.754, p=.084)$ 과 부적상관관계를 보였다.
일반아동.어머니 집단에서 아동 $\mathrm{AD}$ 빈도는 아동 대화차례 발 화 시간 $(\mathrm{r}=-.899, p<.05)$ 과 부적상관관계를 보였다. 또한 어머니 대화차례 쉼 시간과 아동 대화차례 쉼 시간이 정적상관관계를 보 였다 $(\mathrm{r}=.829, p<.05)$.

\section{평가 후 12 개월 시점의 상관 분석}

평가 후 12 개월 시점의 말더듬아동 집단과 일반아동 집단의 $\mathrm{ND}$ 및 $\mathrm{AD}$ 빈도와 아동 요인, 어머니 요인 간의 관계를 스피어만 등위 상관분석한 결과는 Appendix 6과 같다.

말더듬아동·어머니 집단에서 아동 $\mathrm{AD}$ 빈도는 어머니 대화차례 발화 시간 $(\mathrm{r}=-.736, p=.096)$ 과 부적상관관계를 보였다. 또한 어머 니 대화차례 발화 시간과 아동 대화차례 발화 시간이 부적상관관 계를 보였다 $(r=-.829, p<.05)$.

일반아동·어머니 집단에서 아동 ND 빈도는 어머니 대화차례 쉼 시간 $(\mathrm{r}=-.886, p<.05)$ 과 부적상관관계를 보였다.

\section{개별 말더듬아동 및 어머니 상호작용 특성 변화}

개별 말더듬아동 비유창성 빈도와 대화차례 발화 시간 변화

개별 말더듬아동의 비유창성 빈도와 대화차례 발화 시간의 변 화를 살펴보면 Figure 3과 같다. 아동의 ND 및 $\mathrm{AD}$ 빈도는 수치가 큰 관계로 $1 / 10$ 로 축소하여 제시하였다. 평가 후 연구기간 동안 간 접치료와 직접치료를 받았던 CWS3과 CWS4의 경우, 시간의 흐름 에 따라 대화차례 발화 시간은 짧아지고, $\mathrm{ND}$ 및 $\mathrm{AD}$ 빈도가 감소 하는 양상을 보였다. 간접치료를 3개월 동안 받았던 CWS1, CWS2, CWS5의 경우, 대화차례 발화 시간과 $\mathrm{ND}$ 및 $\mathrm{AD}$ 빈도가 다른 양상 을 보였다. 치료를 받지 않았던 CWS6의 경우, 대화차례 발화 시간 은 길어지고, $\mathrm{ND}$ 및 $\mathrm{AD}$ 빈도가 증가하는 양상을 보였다.

\section{개별 말더듬아동 비유창성 빈도와 대화차례 쉼 시간 변화}

개별 말더듬아동의 비유창성 빈도와 대화차례 심 시간 간 변화 를 살펴보면 Figure 4 와 같다. 평가 후 연구기간 동안 간접치료와 직 접치료를 받았던 CWS3과 CWS4의 경우, 시간의 흐름에 따라 대화 차례 쉼 시간은 길어지고, $\mathrm{ND}$ 및 $\mathrm{AD}$ 빈도가 감소하는 양상을 보였 다. 간접치료를 3 개월 동안 받았던 CWS1, CWS2, CWS5의 경우, 대 화차례 쉼 시간과 $\mathrm{ND}$ 및 $\mathrm{AD}$ 빈도가 다른 양상을 보였으며, CWS5 의 경우, 대화차례 심 시간이 짧아지고, $\mathrm{ND}$ 및 $\mathrm{AD}$ 빈도가 증가하 는 경향을 보였다. 치료를 받지 않았던 CWS6의 경우, 대화차례 심 시간은 길어지고, $\mathrm{ND}$ 및 $\mathrm{AD}$ 빈도가 증가하는 양상을 보였다. 


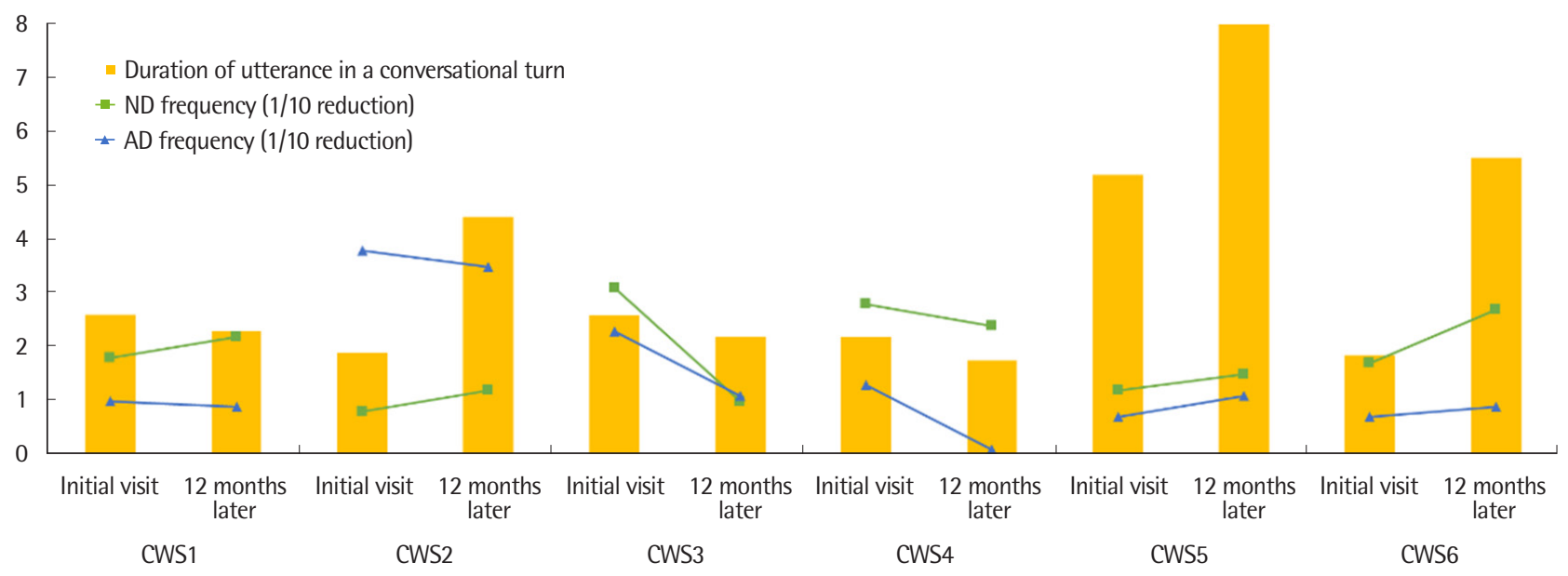

Figure 3. Individual changes in disfluency and duration of utterance in a conversational turn in CWS.

$\mathrm{ND}=$ normal disfluency; $\mathrm{AD}=$ abnormal disfluency; $C W S=$ children who stutter.

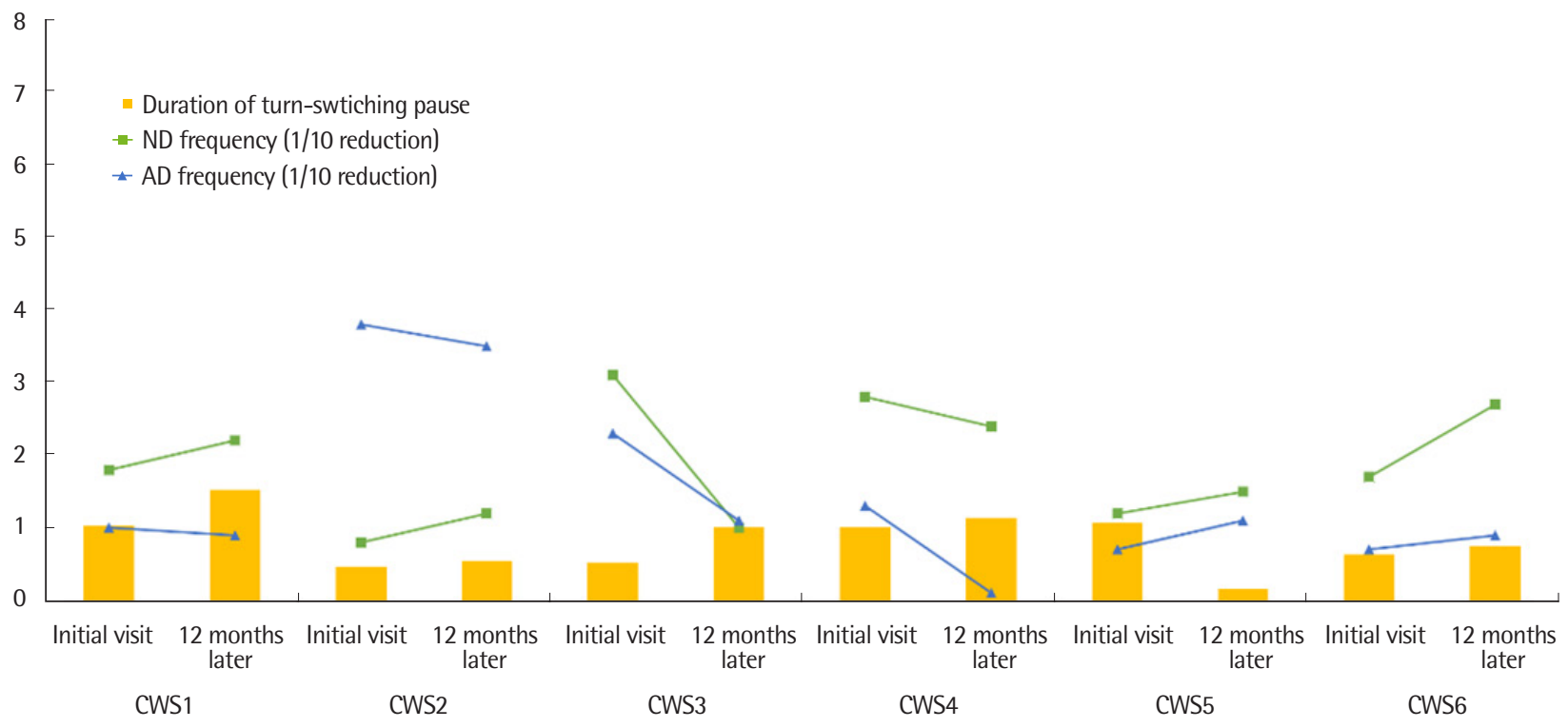

Figure 4. Individual changes in disfluency and duration of turn-switching pause in CWS.

$\mathrm{ND}=$ normal disfluency; $\mathrm{AD}=$ abnormal disfluency; $C W S=$ children who stutter.

개별 말더듬아동 비유창성 빈도와 어머니 대화차례 발화 시간 변화

개별 말더듬아동의 비유창성 빈도와 어머니 대화차례 발화 시 간 간 변화를 살펴보면 Figure 5와 같다. 평가 후 연구기간 동안 간 접치료와 직접치료를 받았던 CWS3과 CWS4의 경우, 시간의 흐름 에 따라 어머니의 대화차례 발화 시간은 길어지고, 아동의 ND 및 $\mathrm{AD}$ 빈도가 감소하는 양상을 보였다. 간접치료를 3개월 동안 받았 던 CWS1, CWS2, CWS5의 경우, 어머니의 대화차례 발화 시간과 $\mathrm{ND}$ 및 $\mathrm{AD}$ 빈도가 다른 양상을 보였으며, CWS2의 경우, 어머니의 대화차례 발화 시간이 짧아지고, 아동의 $\mathrm{AD}$ 빈도는 감소, $\mathrm{ND}$ 빈
도는 증가하는 경향을 보였다. 치료를 받지 않았던 CWS6의 경우, 어머니의 대화차례 발화 시간은 짧아지고, 아동의 ND 및 $\mathrm{AD}$ 빈도 가 증가하는 양상을 보였다.

개별 말더듬아동 비유창성 빈도와 어머니 대화차례 쉼 시간 변화 개별 말더듬아동의 비유창성 빈도와 어머니의 대화차례 심 시간 간 변화를 살펴보면 Figure 6과 같다. 평가 후 연구기간 동안 간접치 료와 직접치료를 받았던 CWS3과 CWS4의 경우, 어머니의 대화차 례 쉼 시간과 아동의 $\mathrm{ND}$ 및 $\mathrm{AD}$ 빈도가 다른 양상을 보였다. $\mathrm{CWS} 3$ 의 경우, 어머니의 대화차례 심 시간은 길어지고, 아동의 ND 


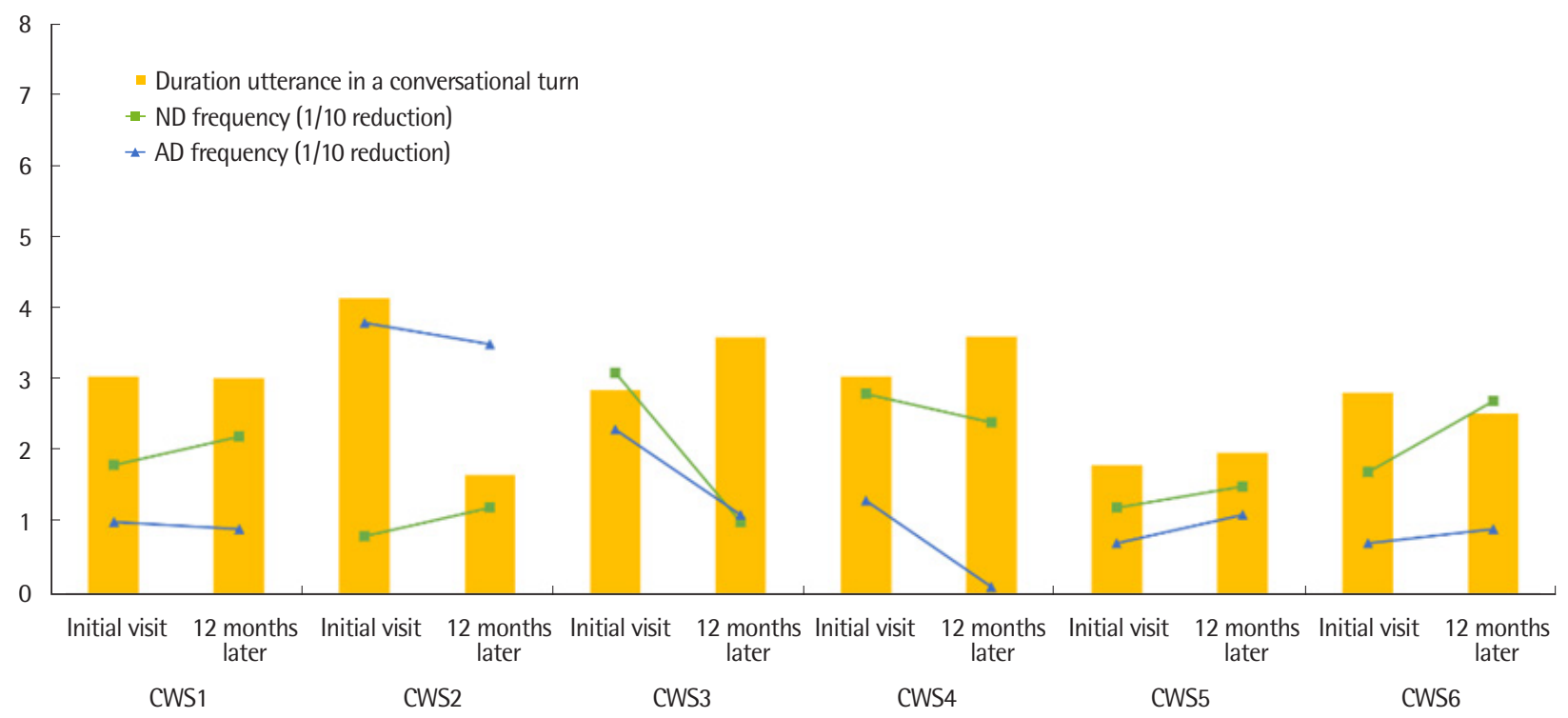

Figure 5. Individual changes in disfluency and duration of utterance in a conversational turn of mothers in CWS. $\mathrm{ND}=$ normal disfluency; $\mathrm{AD}=$ abnormal disfluency; $\mathrm{CWS}=$ children who stutter.

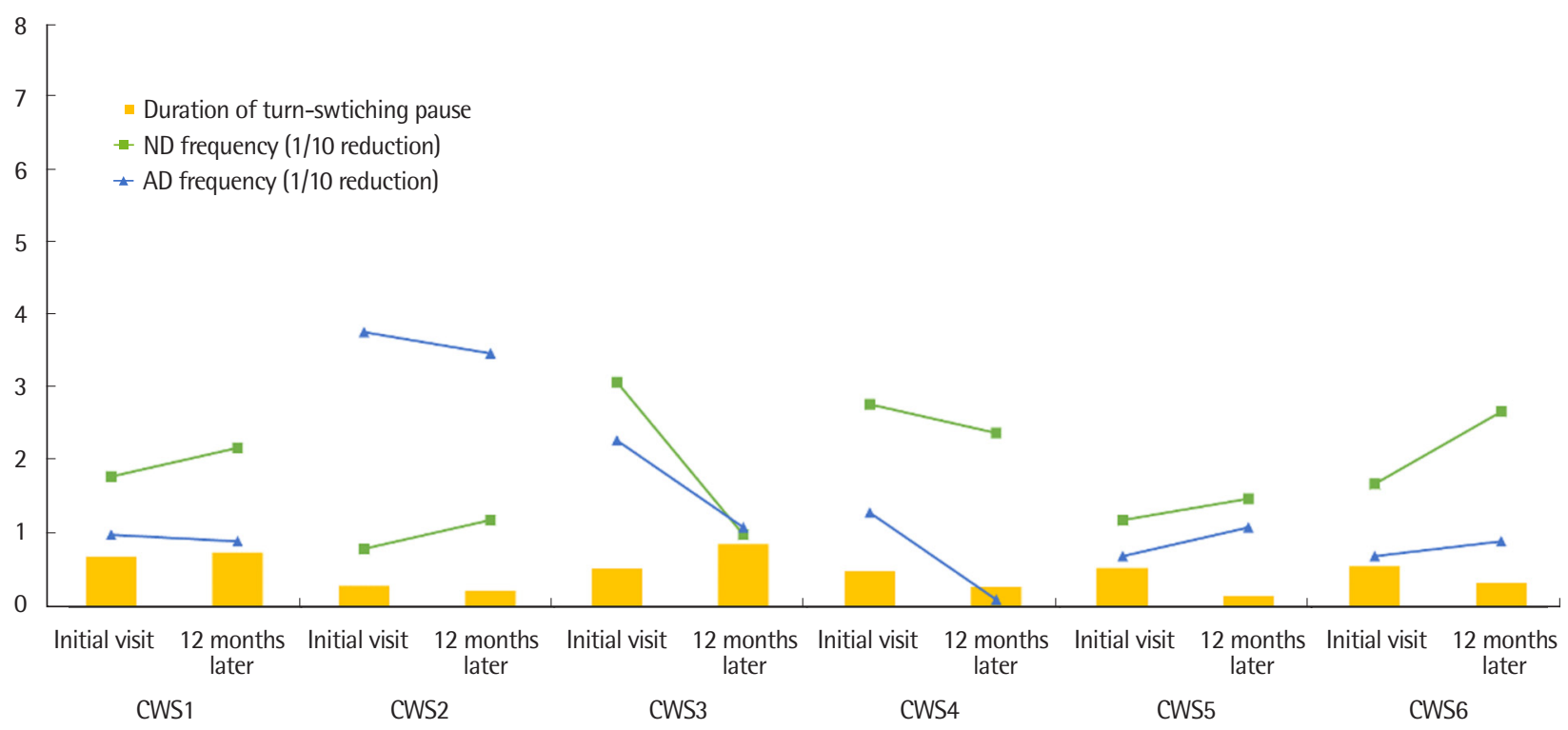

Figure 6. Individual changes in disfluency and duration of turn-switching pause of mothers in CWS.

$\mathrm{ND}=$ normal disfluency; $\mathrm{AD}=$ abnormal disfluency; $\mathrm{CWS}=$ children who stutter.

및 $\mathrm{AD}$ 빈도가 감소하는 양상을 보였고, CWS4의 경우, 어머니의 대화차례 심 시간은 짧아지고, 아동의 $\mathrm{ND}$ 및 $\mathrm{AD}$ 빈도가 감소하는 양상을 보였다. 간접치료를 3개월 동안 받았던 CWS1, CWS2, $\mathrm{CWS} 5$ 의 경우, 어머니의 대화차례 발화 시간과 아동의 ND 및 $\mathrm{AD}$ 빈도가 다른 양상을 보였으며, CWS5의 경우, 어머니의 대화차례 쉼 시간이 짧아지고, 아동의 $\mathrm{AD}$ 빈도는 감소, $\mathrm{ND}$ 빈도는 증가하 는 경향을 보였다. 치료를 받지 않았던 CWS6의 경우, 어머니의 대
화차례 쉼 시간은 짧아지고, 아동의 $\mathrm{ND}$ 및 $\mathrm{AD}$ 빈도가 증가하는 양상을 보였다.

\section{논의 및 결론}

본 연구는 학령전 말더듬아동과 어머니가 일상에서 대화하면서 상호작용할 때 나타나는 대화차례 발화 시간과 대화차례 심 시간 
이 아동의 비유창성과 어떠한 관련이 있는지를 종단적으로 분석하 였다. 아울러 말더듬아동과 어머니의 상호작용 특성을 일반아동 집단과 비교했을 때 차이를 보이는가를 살펴보았다. 그 결과에 대 한 논의는 다음과 같다.

첫째, 평가 시점에서 말더듬아동 집단의 $\mathrm{AD}$ 빈도가 일반아동 집단의 $\mathrm{AD}$ 빈도보다 통계적으로 유의하게 높은 것으로 나타났고, 평가 후 12 개월 시점에서는 통계적으로 유의한 차이가 없는 것으 로 나타났다. 이러한 결과는 각 시점에서 나타난 개별 말더듬아동 의 $\mathrm{AD}$ 빈도 차이가 큰 특성에서 비롯되는 것으로 사료된다. 말더 듬아동은 유창성을 저해하는 자극에 의해 일반아동보다 더 많은 영향을 받으며, 그와 같은 취약성(vulnerability)으로 인해 비유창 성 변화의 폭이 크게 나타나는데(Lee \& Sim, 2007; Min, 2007), 본 연구에 참여한 개별 말더듬아동을 살펴보았을 때, 평가 시점에서 가장 낮은 $\mathrm{AD}$ 빈도를 보인 아동은 7 회를 보였으며, 가장 높은 $\mathrm{AD}$ 빈도를 보인 아동은 38 회였다. 평가 후 12 개월 시점에서 가장 낮은 $\mathrm{AD}$ 빈도를 보인 아동은 1 회를 보였으며, 가장 높은 $\mathrm{AD}$ 빈도를 보 인 아동은 35 회였다. 개별 아동 내에서 시점 간 $\mathrm{AD}$ 빈도 차가 가장 큰 경우는 12 회였으며, 가장 작은 경우는 1 회였다. 본 연구의 결과 는 말더듬아동을 집단뿐만 아니라 개별로 살펴보는 것이 중요하 며, 가변성(variability)이 큰 말더듬의 특성을 잘 반영한다고 할 수 있다. 또한 평가 후 연구 기간 동안 간접 및 직접치료를 받고 있었던 CWS3과 CWS4는 ND와 $\mathrm{AD}$ 빈도가 감소하는 경향을 보였으나 간접치료를 받았던 CWS1은 감소, CWS2, CWS5는 증가하는 경향 을 보여 치료효과 외에 다른 요인들과 종합적으로 살펴보아야 할 것이다.

각 집단에서 시점 간 아동의 $\mathrm{ND}$ 및 $\mathrm{AD}$ 빈도에 통계적으로 유의 한 차이가 없는 것으로 나타났으나 일반아동 집단의 경우, $\mathrm{ND}$ 빈 도가 평가 시점보다 평가 후 12 개월 시점에서 증가하는 것으로 나 타났다. 이러한 결과는 아동의 연령이 증가함에 따라 점차 감소하 는 양상을 보인다고 한 선행연구와는 상반되는 결과이며(Min, 2007), 말더듬아동 뿐만 아니라 일반아동도 말언어능력이 발달하 는 중에 있고 주변 환경이 계속해서 변화하므로 비유창성이 빈번하 게 나타날 수 있다. 더불어 $\mathrm{AD}$ 빈도 역시 높은 빈도를 유지하고 있 고 시점 간 비유창성 빈도가 큰 변동(fluctuation)을 보일 수 있으므 로(Yairi, 1982) 이들의 비유창성도 종단적으로 주의 깊게 살필 필 요가 있음을 시사한다.

둘째, 평가 시점과 평가 후 12 개월 시점에서 말더듬아동 어머니 집단과 일반아동 어머니 집단 간 대화차례 발화 시간과 대화차례 쉼 시간에 유의한 차이가 없는 것으로 나타났다. 이는 말더듬아동 부모가 일반아동 부모와 다른 방식으로 의사소통하고, 말더듬아
동 부모의 시간적 요인이 아동의 말더듬을 발생 및 지속시킬 정도 로 나타난다는 선행연구와는 일치하지 않는 결과이다(Allan \& Williams, 1974; Egolf, Shames, Johnson, \& Kasprisin-Burrelli, 1972; Johnson, 1955; Johnson \& Associates, 1959; KasprisinBurrelli, Egolf, \& Shames, 1972; Meyers \& Freeman, 1985a, b). 대 화차례 발화 시간은 대화의 독점 또는 경쟁 여부를 판단할 수 있는 측정치로, 아동과 부모의 대화차례가 불균형을 이루게 될 때, 아동 이 대화차례를 얻기 위해 부모와 경쟁하게 될 수 있다고 하였다. 또 한 부모의 심 시간이 짧으면 아동은 빠르게 대답해야 한다는 압박 을 느끼게 되고(Manning, 2010), 압박을 느낀 아동은 짧은 대화차 례 쉼 시간을 보이게 되어 아동이 발화를 계획하고 산출하는 말운 동 시스템에 과부하를 초래하여 말더듬 행동이 나타나게 하거나 악화시키는 결과를 초래할 수 있다고 하였다(Conture, 1990; Savelkoul et al., 2007). 그러나 본 연구에서는 말더듬아동 어머니가 일반 아동 어머니보다 긴 대화차례 발화 시간과 짧은 대화차례 심 시간 을 보이지 않았고, 이러한 결과는 대화차례 쉼 시간이 말더듬아동 어머니와 일반아동 어머니 간 차이가 없고, 말더듬아동 어머니와 일반아동 어머니가 시간적 요인에서 차이가 없다고 한 선행연구와 일치한다(Kelly \& Conture, 1992; Zebrowski, 1995).

셋째, 평가 시점과 평가 후 12 개월 시점에서 말더듬아동 집단과 일반아동 집단 간 대화차례 발화 시간과 대화차례 쉼 시간에 통계 적으로 유의한 차이가 없는 것으로 나타났다. 즉, 말더듬아동이 일 반아동보다 긴 대화차례 발화 시간과 짧은 대화차례 심 시간을 보 이지 않았다. 이러한 결과는 말더듬아동이 부모와 상호작용 시, 부 모가 본인의 발화를 방해하고, 본인을 표현하는데 부모로부터 제 약(constraint)을 느껴 부모의 발화에 반응하지 않거나 본인의 대 화차례 시 발화하는 것을 포기할 수 있다고 한 선행연구와는 일치 하지 않는 결과이다(Langlois, Hanrahan, Inouye, 1986; Zebrowski \& Kelly, 2002).

또한 각 집단에서 시점 간 아동의 대화차례 발화 시간 및 쉼 시간 에 통계적으로 유의한 차이가 없는 것으로 나타났으나 두 집단 모 두 대화차례 발화 시간이 평가 시점보다 평가 후 12 개월 시점에서 길어지는 것으로 나타났다. 본 연구에서는 아동의 평균 형태소 길 이(Mean Length of Utterance in morphemes, MLU-m)와 어휘다 양도(Type-Token Ratio, TTR)를 분석하지 않아 아동 발화의 길이 와 복잡도를 알 수 없으나 학령전 아동의 말언어능력의 형식뿐 아 니라 내용과 사용 면에서 괄목할 만한 성장을 보이므로(Bae, 2021) 이러한 결과를 보였을 것으로 사료된다.

넷째, 말더듬아동·어머니 집단의 경우, 평가 시점에서 아동 $\mathrm{AD}$ 빈도는 어머니 대화차례 발화 시간과 정적상관관계를 보였고, 아동 
대화차례 쉼, 어머니 대화차례 쉼과 부적상관관계를 보였다. 이는 아동과 부모의 대화차례가 불균형을 이루게 되어 아동이 대화차 례를 얻기 위해 부모와 경쟁하게 만들 수 있다는 선행연구와 일치 하는 결과이다(Manning, 2010; Savelkoul et al., 2007; Winslow \& Guitar, 1994). 또한 부모가 아동의 발화에 반응하기 위해 충분한 기다림을 제공하는 것이 시간적 압박을 감소시켜 주어 아동의 유 창성을 증진시키는데 긍정적인 영향을 미칠 수 있다고 한 선행연구 와 일치하는 결과이다(Conture, 1990; Craig \& Gallagher, 1983).

그러나 평가 후 12 개월 시점에서는 평가 시점과 달리 아동 $\mathrm{AD}$ 빈 도와 어머니 대화차례 발화 시간이 부적상관관계를 보였고, 어머니 대화차례 발화 시간과 아동 대화차례 발화 시간이 부적상관관계 를 보였다. 즉, 어머니의 대화차례 발화 시간이 길어질수록 아동의 대화차례 발화 시간은 짧아지고 $\mathrm{AD}$ 빈도는 감소하며, 어머니의 대 화차례 발화 시간이 짧아질수록 아동의 대화차례 발화 시간은 길 어지고 $\mathrm{AD}$ 빈도는 증가하는 양상을 보였다. 이러한 결과는 한 대화 참여자의 행동 변화가 다른 대화 상대자의 행동을 같은 방향으로 변화시키고, 부모의 대화차례 발화 시간이 아동의 대화차례 발화 시간보다 길 경우, 아동과 부모의 대화차례가 불균형을 이루게 되 어 아동이 대화차례를 얻기 위해 부모와 경쟁하게 만들 수 있다는 선행연구와는 일치하지 않는 결과이다(Manning, 2010; Savelkoul et al., 2007; Winslow \& Guitar, 1994). 본 연구에서는 어머니의 대 화차례 발화 시간이 짧아질수록 아동의 대화차례 발화 시간은 길 어지고, 아동의 $\mathrm{AD}$ 빈도는 증가하는 양상을 보였는데, 이는 부모 의 대화차례 발화 시간과 관계없이 아동이 본인의 대화차례 발화 시간을 길게 하여 스스로 시간적 압박을 부과(self-imposed time urgency)하고(Zebrowski \& Kelly, 2002), 이러한 압박이 인지적, 언 어적, 운동적, 정서적 용량을 초과하여 아동의 비유창성을 증가시 키는데 영향을 미쳤을 것(Kim \& Sim, 2021)으로 사료된다. 본 연구 의 결과는 아동. 부모 상호작용 치료와 같은 간접치료 뿐만 아니라 아동의 발화를 변화시키는 직접치료도 중요함을 나타내며, 직접치 료 시, 말더듬아동의 발화 양과 발화 길이 및 복잡도를 조절해줄 필 요가 있음을 시사한다(Lee \& Sim, 2015; Logan \& Conture, 1995). Lee와 $\operatorname{Sim}$ (2015)은 비유창한 발화 길이가 길어지면서 비유창성이 증가하는 것을 줄이기 위해 비유창한 문장의 길이를 조절해주는 치료가 필요함을 제언하였다. 후속연구에서는 아동과 어머니 간 상 호작용 시 나타난 아동의 대화차례 발화 시간을 유창한 대화차례 발화 시간과 비유창한 대화차례 발화 시간으로 구분하면서 아동 의 비유창성이 어떻게 변화하는지 살펴볼 필요가 있을 것으로 사 료된다.

또한 본 연구 결과는 학령전 말더듬아동의 비유창성과 관련 있
는 요인이 아동의 연령이 증가함에 따라 달라질 수 있으므로 (Smith \& Kelly, 1997) 향후 대단위 종단연구의 필요성을 제시하며, 학령전 말더듬아동을 치료하는 동안 언어재활사가 치료 시점 별로 살펴보아야 할 요인들이 달라질 수 있음(Lee \& Sim, 2016)을 시사 한다.

일반아동.어머니 집단의 경우, 평가 시점에 아동 $\mathrm{AD}$ 빈도는 아 동 대화차례 발화 시간과 부적상관관계를 보였고, 어머니 대화차례 쉼 시간과 아동 대화차례 쉼 시간이 정적상관관계를 보였다. 평가 후 12 개월 시점에서는 아동 ND 빈도가 어머니 대화차례 심 시간과 부적상관관계를 보였다. 즉, 어머니 대화차례 쉼 시간이 짧을수록 $\mathrm{ND}$ 빈도가 증가하고, 길수록 ND 빈도가 감소했다는 것을 나타낸 다. 말더듬아동 뿐만 아니라 일반아동도 성장하는 중에 있으므로 $\mathrm{ND}$ 와 $\mathrm{AD}$ 를 보일 수 있는데, 본 연구 결과는 어머니가 아동과 상호 작용 시, 긴 대화차례 쉼 시간을 사용하면 학령전 아동의 비유창성 이 감소된다고 한 선행연구 결과와 일치한다(Ahn et al., 2009; Lee \& Sim, 2016; Newman \& Smit, 1989).

말더듬아동 어머니 집단과 일반아동 어머니 집단에서 아동의 비유창성과 부적상관관계를 보였던 어머니 대화차례 심 시간을 좀 더 살펴보면, 각 집단의 개별 양상을 살펴보았을 때 어머니의 평균 대화차례 쉼 시간은 0-1초로 나타났다. 선행연구에서는 2-3초의 대 화차례 심 시간을 부모에게 권고하는 것이 적정하다고 보고 있는 데, 본 연구 결과에 따르면 0-1초의 대화차례 심 시간이 아동의 말 더듬 발생 및 지속에 영향을 미칠 정도로 짧은 것인지에 대해 검토 할 필요성이 있다. 상호작용 치료 시 모든 말더듬아동 부모에게 2-3 초의 대화차례 쉼 시간을 권하는 것보다는 부모와 아동의 개별적 인 상호작용 특성에 따라 대화차례 심 시간을 다르게 적용해야 할 것으로 보인다(Lee \& Sim, 2016).

말더듬아동.어머니 집단을 개별적으로 살펴보았을 때, 경향성을 보이기보다는 각 개별 양상과 치료 효과가 개별적으로 상이하게 나 타났다. 평가 후 연구기간 동안 간접치료와 직접치료를 받았던 아 동들은 $\mathrm{ND}$ 및 $\mathrm{AD}$ 빈도가 감소하였는데, 아동의 대화차례 발화 시 간과 쉼 시간, 어머니의 대화차례 발화 시간은 같은 경향을 보였으 나 부모의 대화차례 심 시간이 다른 양상을 보였다. 간접치료를 3 개 월 동안 받았던 아동들은 $\mathrm{ND}$ 및 $\mathrm{AD}$ 빈도 뿐만 아니라 아동과 어 머니의 대화차례 발화 시간과 쉼 시간이 다른 양상을 보였다. 치료 를 받지 않았던 아동은 $\mathrm{ND}$ 및 $\mathrm{AD}$ 빈도가 증가하였는데, 아동의 대화차례 발화 시간과 대화차례 심 시간이 길어졌고, 어머니의 대 화차례 발화 시간과 대화차례 심 시간은 짧아지는 경향을 보였다. 이러한 연구결과는 말더듬아동과 부모의 개별적인 특성을 고려하 여 간접 및 직접치료 방법을 적용하는 것이 중요하며, 간접치료 뿐 
만 아니라 직접치료도 받은 아동의 경우, 어머니와의 상호작용 시, 대화차례 발화 시간이 길어지거나 대화차례 심 시간이 짧아져도, 즉 주변의 환경 변화와 상관없이 아동 스스로 본인의 대화차례 발 화 시간과 쉼 시간을 조절할 수 있고, 이러한 점이 비유창성 빈도 변 화에 영향을 줄 수 있다는 점을 시사한다.

후속연구를 위한 본 연구의 한계점과 제언은 다음과 같다. 첫째, 본 연구의 연구대상자 수가 각 집단별 6쌍으로 제한적이며, 개별 말 더듬아동의 중재 기간 및 중재 방법에 제한을 두지 않았고, 말더듬 아동의 대부분은 말더듬 시작 시점이 1 년 이내였으나 5 번 말더듬 아동이 1 년을 초과하여 대상자의 배경 변인을 통제하지 못하였다. 후속 연구에서는 더 많은 대상자 수를 확보하고 배경 변인을 통제 하여 종속 변인들을 분석할 필요가 있다. 둘째, 아동과 부모의 대화 차례 발화 시간, 아동의 대화차례 심 시간에 대해 다룬 선행연구가 국내외로 거의 없는 실정이어서 결과 해석에 어려움이 있었다. 후속 연구에서는 해당 변인들을 통제하였을 때 학령전 아동의 비유창성 이 어떻게 변화하는지 분석할 필요가 있다. 셋째, 말더듬아동 집단 뿐만 아니라 일반아동 집단의 개별 양상도 분석하면 임상현장에 서 말더듬아동의 특성을 파악하고 중재하는데 도움이 될 것으로 기대한다. 이러한 한계점과 제언을 고려하여 후속연구가 이루어진 다면, 말더듬 발생 및 지속과 관련 있는 아동과 부모의 상호작용 특 성에 대한 정보와 학령전 말더듬아동에게 적절한 중재 방법을 제 공하기 위한 근거를 더욱 명확히 할 수 있을 것으로 기대한다.

\section{REFERENCES}

Ahn, J. H., Shin, J. C., Kim, H. H., \& Sim, H. S. (2009). Change of dysfluency of pre-school children who stuttering according to modification of articulation rate and response latency time. Journal of Speech-Language \& Hearing Disorders, 18(4), 123-138.

Ambrose, N. G., \& Yairi, E. (1999). Normative disfluency data for early childhood stuttering. Journal of Speech, Language, and Hearing Research, 42(4), 895-909.

Allan, F., \& Williams, C. L. (1974). Interaction patterns of families containing a stuttering sibling. Australian Journal of Human Communication Disorders, 2(1), 32-40.

Bae, H. S. (2021). Language development (2nd). Seoul: Hakjisa.

Boersma, P., \& Weenink, D. (2012). Praat: doing phonetics by computer (version 5.3.16) [software]. http://www.praat.org.

Choi, J. E., \& Lee, Y. (2013). Conversational turn-taking and topic manipulation skills of children with high functioning autism spectrum disorders.
Communication Sciences \& Disorders, 18(1), 12-23.

Chon, H., \& Lee, S. (2016). Effects of stuttering severity on articulation rate in fluent and dysfluent utterances of preschool children who stutter. Phonetics and Speech Sciences, 8(3), 79-90.

Chon, H., Sawyer, J., \& Ambrose, N. G. (2012). Differences of articulation rate and utterance length in fluent and disfluent utterances of preschool children who stutter. Journal of Communication Disorders, 45(6), 455-467.

Conture, E. G. (1990). Stuttering. Englewood Cliffs, NJ: Prentice-Hall.

Craig, H. K., \& Gallagher, T. M. (1983). Adult-child discourse: the conversational relevance of pausing. Journal of Pragmatic, 7(4), 347-360.

Egolf, D. G., Shames, G. H., Johnson, P. R., \& Kasprisin-Burrelli, A. (1972). The use of parent-child interaction patterns in therapy for young stutters. Journal of Speech and Hearing Disorders, 37(2), 222-232.

Guitar, B. (2013). Stuttering: an integrated approach to its nature and treatment (4th ed). Philadelphia, PA: Wolters Kluwer Health/Lippincott Williams \& Wilkins.

Hall, K. D., Amir, O., \& Yairi, E. (1999). A longitudinal investigation of speaking rate in preschool children who stutter. Journal of Speech, Language, and Hearing Research, 42(6), 1367-1377

Heo, H., \& Lee, Y. (2012). Conversational turn-taking and topic manipulation skills in conversations of school-age low-achievers in language learning. Korean Journal of Communication \& Disorders, 17(1), 66-78.

Johnson, W. (1955). A study of the onset and development of stuttering. In W. Johnson \& R. Leutenegger (Eds.), Stuttering in children and adults (pp.3773). Minneapolis, MN: University of Minnesota Press.

Johnson, W., \& Associates (1959). The onset of stuttering. Minneapolis, MN: University of Minnesota Press.

Kasprisin-Burrelli, A., Egolf, D. B., \& Shames, G. H. (1972). A comparison of parental verbal behaviors with stuttering and non-stuttering children. Journal of Communication Disorders, 5(4), 335-346.

Kefalianos, E., Onslow, M., Packman, A., Vogel, A., Pezic, A., Mensah, F., \& Reilly, S. (2017a). The history of stuttering by 7 years of age: follow-up of a prospective community cohort. Journal of Speech, Language, and Hearing Research, 60 (10), 2828-2839.

Kefalianos, E., Onslow, M., Ukoumunne, O. C., Block, S., \& Reilly, S. (2017b). Temperament and early stuttering development: cross-sectional findings from a community cohort. Journal of Speech, Language, and Hearing Research, 60(4), 772-784.

Kelly, E. M. (1994). Speech rates and turn-taking behaviors of children who stutter and their fathers. Journal of Speech and Hearing Research, 37(6), 
1284-1294.

Kelly, E. M., \& Conutre, E. G. (1992). Speaking rates, response time latencies, and interrupting behaviors of young stutters, nonstutterers, and their mother. Journal of Speech and Hearing Research, 35(6), 1256-1267.

Kloth, S., Janssen, P., Kraaimaat, F., \& Brutten, G. (1998). Child and mother variables in the development of stuttering among high-risk children: A longitudinal study. Journal of Fluency Disorders, 20, 217-230.

Kloth, S., Janssen, P., Kraaimaat, F., \& Brutten, G. (1999). Persistence and remission of incipient stuttering among high-risk children. Journal of Fluency Disorders, 24, 253-256.

Kim, Y. (2014). Assessment and intervention of child language disorders (2nd ed.). Seoul: Hakjisa.

Kim, Y., \& Shin, M. (2016). The effects of parents education on reducing disfluencies of their preschool children who stutter. Special Education Research, 15(3), 59-74.

Kim, Y. T., Hong, G. H., Kim, K. H., Jang, H. S., \& Lee, J. Y. (2009). Receptive \& expressive vocabulary test (REVT). Seoul: Seoul Community Rehabilitation Center.

Kin, Y. T., \& Shin, M. J. (2004). Urimal Test of Articulation and phonology (UTAP). Seoul: Hakjisa.

Kim, Y., \& Sim, H. (2021). The influencies of speech rate, utterance length and sentence complexity of disfluency in preschool children who stutter and children who do not stutter. Phonetics and Speech Sciences, 13(1), 5364.

Langlois, A., Hanrahan, L. L., \& Inouye, L. L. (1986). A comparison of interactions between stuttering children, nonstuttering children, and their mothers. Journal of Fluency Disorders, 11(3), 263-273.

Lee, S. B. (2014). The longitudinal study of treatment effect predictors in early childhood stuttering (Doctoral dissertation). Ewha Womans University, Seoul, Korea.

Lee, S., Kwak, H., Yun, J., Shin, D., \& Sim, H. (2020). Development of the video-based smart utterance deep analyser (SUDA) application. Phonetics and Speech Sciences, 12(2), 63-72.

Lee, E., \& Sim, H. S. (2007). Temperament of preschool children who stutter and mother's temperament and parenting style. Korean Journal of Communication \& Disorders, 12(2), 279-25.

Lee, S. B., \& Sim, H. S. (2015). A longitudinal study of utterance length in morphemes as a predictor of treatment outcome in early childhood stuttering. Communication Sciences \& Disorders, 20(2), 189-201.

Lee, S. B., \& Sim, H. S. (2016). Fluency predictor variables in early stuttering intervention for children. Communication Sciences \& Disorders, 21(2), 382-396.

Lee, S. B., Park, H. Y., \& Sim, H. S. (2019). Research trends on longitudinal stuttering studies. Communication \& Sciences \& Disorders, 24(2), 490-506.

Logan K. J., \& Conture, E. G. (1995). Length, grammatical complexity, and rate differences in stuttered and fluent conversational utterances of children who stutter. Journal of Fluency Disorders, 20(1), 35-61.

Manning, W. H. (2010). Clinical decision making in fluency disorders (3rd ed). Clifton Park, NY: Delmar Cengage Learning.

Meyers, S. C., \& Freeman, F. J. (1985a). Mother and child speech rates as a variable in stuttering and disfluency. Journal of Speech and Hearing Research, 28(3), 436-444.

Meyers, S. C., \& Freeman, F. J. (1985b). Interruptions as a variable in stuttering and disfluency. Journal of Speech and Hearing Research, 28(3), 428-435.

Min, K. (2007). Variability in the frequency of disfluencies produced by stuttering and nonstuttering children in three speaking tasks (Master's thesis). Ewha Womans University, Seoul, Korea.

Newman, L. L., \& Smit, A. B. (1989). Some effects of variations in response time latency on speech rate, interruptions, and fluency in children's speech. Journal of Speech and Hearing Research, 32(3), 635-644

Ok, J., \& Rhee, K. (2003). The effects of parent involvement in stuttering children. Korean Journal of Special Education, 38(2), 153-175.

Owens, R. E. (2004). Language disorders: a functional approach to assessment and intervention. Boston. MA: Allyn \& Bacon.

Paden, E. P., Ambrose, N. G., \& Yairi, E. (2002). Phonological progress during the first 2 years of stuttering. Journal of Speech, Language, and Hearing Research, 45(2), 256-267,

Park, H. Y., Lee, S. B., \& Sim, H. S. (2015). Communication behaviors of stuttering recovery and stuttering persistent groups. Journal of Speech-Language \& Hearing Disorders, 24(4), 237-248.

Park, Y. R., \& Choi, S. Y. (2019). The effects of conversational skills intervention through group program on conversational turn-taking and topic manipulation skills of school-age children with language delay. Journal of Speech-Language \& Hearing Disorders, 28(2), 115-128.

Ratner, N. B. (1992). Measurable outcomes of instructions to modify normal parent-child verbal interactions: Implications for indirect stuttering therapy. Journal of Speech and Hearing Research, 35(1), 14-20.

Ratner, N. B. (2004). Caregiver-child interactions and their impact on children's fluency: Implications for treatment. Language, Speech, and Hearing Services in School, 35(1), 46-56. 
Savelkoul, E. M., Zebrowski, P. M., Feldstein, S., \& Cole-Harding, S. (2007). Coordinated interpersonal timing in the conversations of children who stutter and their mothers and fathers. Journal of Fluency Disorders, 32(1), $1-32$.

Sawyer, J., \& Yairi, E. (2010). Characteristics of disfluency clusters over time in preschool children who stutter. Journal of Speech, Language, and Hearing Research, 53(3), 1191-1205.

Smith, A., \& Kelly, E. (1997). Stuttering: a dynamic, multifactorial model. In R. F. Curlee \& G. M. Siegel (Eds.). Nature and treatment of stuttering: new directions (2nd ed., pp. 204-217). Boston, MA; Allyn \& Bacon.

Smith, K. A., Iverach, L., O’Brian, S., Mensah, F., Kefalianos, E., Hearne, A., \& Reilly, S. (2017). Anxiety in 11-year-old children who stutter: findings from a prospective longitudinal community sample. Journal of Speech, Language, and Hearing Research, 60(5), 1211-1222.

Sim, H. S., Shin, M. J., \& Lee, E. J. (2010). Paradise-Fluency assessment II. Seoul: Paradise Welfare Foundation.

Throneburg, R. N., \& Yairi, E. (2001). Durational, proportionate, and absolute frequency characteristics of disfluencies. Journal of Speech, Language, and Hearing Research, 44(1), 38-51.

Usler, E., Smith, A., \& Weber, C. (2017). A lag in speech motor coordination during sentence production is associated with stuttering persistence in young children. Journal of Speech, Language, and Hearing Research, 60(1), 51-61.
Wagovich, S. A., Hall, N. E., \& Clifford, B. A. (2009). Speech disruptions in relation to language growth in children who stutter: an exploratory study. Journal of Fluency Disorders, 34(4), 242-256.

Watts, A., Eadie, P., Block, S., Mensah, F., \& Reilly, S. (2017). Language skills of children during the first 12 months after stuttering onset. Journal of Fluency Disorders, 51, 39-49.

Winslow, M., \& Guitar, B. (1994). The effect of structured turn-taking on disfluencies: a case study. Language, Speech, and Hearing Services in Schools, 25(4), 251-257.

Yairi, E. (1982). Longitudinal studies of disfluencies in two-year-old children. Journal of Speech, Language, and Hearing Research, 25(1), 155-160.

Yairi, E., \& Ambrose, N. G. (1999). Early childhood stuttering I: persistency and recovery rates. Journal of Speech, Language, and Hearing Research, 42(5), 1097-1112.

Zebrowski, P. M. (1991). Preliminary acoustic analysis of the perceptually fluent speech and stuttering children before and after intensive therapy. In H. Peters, W. Hulstijn, \& C. W. Starkweather (Eds.), Speech motor control and stuttering (pp 423-429). Amsterdam: Elsevier Science Publishers.

Zebrowski, P. M. (1995). Temporal aspects of the conversations between children who stutter and their parents. Topics in Language Disorders, 15(3), $1-17$.

Zebrowski, P. M., \& Kelly, E. M. (2002). Manual of stuttering intervention. Clifton Park: Thomson-Delmar Learning. 
Appendix 1. 발화 구분 및 선택 기준

발화 구분 및 선택 기준

예

1. 종결어미가 있으면 발화를 구분한다.

2. 끝이 분명하게 내려가거나 올라가는 억양이 나타난 경우, 발화를 구분한다. 단문 두 개가 연결어미로 이어진 하나의 문 장 내에서도 억양 변화가 있으면 발화를 구분한다. 단, 비유창성으로 인해 억양 변화가 나타난 경우에는 발화를 구분하 지 않는다.

3. 발화 간의 쉼이 2 초 이상일 경우 다른 발화로 간주한다. 단, 막힘과 연장과 같은 비유창성으로 인해 2초 이상의 쉼이 나 타난 경우에는 발화를 구분하지 않는다.

4. 상호작용 놀이와 관련 없는 발화는 발화 선택에서 제외한다.

5. 완전 이해 가능한 경우만 발화로 간주하고 조음정확도가 부정확하거나 대화 상대자의 발화와 중첩이 있더라도 전사할 수 있는 음절이 전체 음절의 $50 \%$ 이상일 경우 발화로 간주한다.

6. 노래하거나 숫자세기 등의 기계적 발화는 발화 선택에서 제외한다. 예외로 발화 속에 내포되어 있을 경우에는 발화로 선 (1) 아동: "일, 이, 삼, 사, 오, 육" 택한다. $\rightarrow$ 아동의 발화 선택에서 제외

(2) 아동: "나 일이삼사 알아" $\rightarrow$ 아동의 발화로 선택

7. 긍정이나 부정을 나타내는 1-2음절 발화(예: 네, 응, 그래, 아니)와 현재 화자의 대화차례에서 나타난 대화 상대방의 추 임새(응, 으음 등)는 발화 선택에서 제외한다.

(1) 부모: "엄마 따라해?"

아동: 응

$\rightarrow$ 아동의 발화 선택에서 제외

(2) 아동: 엄마 주황색 좋아하는데 부모: 맞아

$\rightarrow$ 부모의 발화 선택에서 제외

8. 의성어나 의태어는 단순 발성이 아닌 의미 있는 것일 때만 낱말로 인정하므로 단순 발성으로 나타난 의성어와 의태어는 발화 선택에서 제외한다.

(1) 아동: (찰흙을 누르며) "영차 영차 영차" $\rightarrow$ 아동의 발화 선택에서 제외

(2) 아동: 엄마 소도 씻겨 줘 부모: "쓱쓱 싹싹" $\rightarrow$ 부모의 발화 선택에서 제외

Appendix 2. 평가 시점과 평가 후 12 개월 시점에 나타난 아동의 ND 및 $\mathrm{AD}$ 빈 도 평균과 표준편차

\begin{tabular}{lclr}
\hline Period & Disfluency type & \multicolumn{1}{c}{ CWS (N=6) } & CWNS (N=6) \\
\hline Initial visit & $\mathrm{ND}$ & $19.00(8.94)$ & $8.67(3.67)$ \\
& $\mathrm{AD}$ & $16.33(12.16)$ & $2.67(1.75)$ \\
12 months later & $\mathrm{ND}$ & $18.33(6.95)$ & $13.17(6.64)$ \\
& $\mathrm{AD}$ & $12.67(11.55)$ & $2.83(3.66)$
\end{tabular}

Vales are presented as Mean (SD).

$N D=$ normal disfluency; $A D=$ abnormal disfluency; $C W S=$ children who stutter; CWNS = children who do not stutter.
Appendix 3. 평가 시점과 평가 후 12 개월 시점에 나타난 어머니의 대화차례 발 화 시간 및 대화차례 쉼 시간 평균과 표준편차

\begin{tabular}{|c|c|c|c|}
\hline Period & Duration type & CWS $(N=6)$ & CWNS $(\mathrm{N}=6)$ \\
\hline \multirow[t]{2}{*}{ Initial visit } & $\begin{array}{l}\text { Utterance in a conversational } \\
\text { turn (sec) }\end{array}$ & $2.95(.75)$ & $3.13(.76)$ \\
\hline & Turn-switching pause (sec) & $.52(.13)$ & $.62(.22)$ \\
\hline \multirow[t]{2}{*}{$\begin{array}{l}12 \text { months } \\
\text { later }\end{array}$} & $\begin{array}{l}\text { Utterance in a conversational } \\
\text { turn (sec) }\end{array}$ & $2.73(.82)$ & $2.20(1.01)$ \\
\hline & Turn-switching pause (sec) & $.43(.30)$ & $.59(.27)$ \\
\hline
\end{tabular}

Vales are presented as Mean (SD)

CWS = children who stutter; CWNS = children who do not stutter. 
Appendix 4. 평가 시점과 평가 후 12 개월 시점에 나타난 아동의 대화차례 발화 시간 및 대화차례 쉼 시간 평균과 표준편차

\begin{tabular}{lccc}
\hline Period & Duration type & CWS (N=6) & CWNS (N=6) \\
\hline Initial visit & $\begin{array}{c}\text { Utterance in a conversational } \\
\text { turn (sec) }\end{array}$ & $2.72(1.26)$ & $2.42(.42)$ \\
& Turn-switching pause (sec) & $.79(.28)$ & $1.21(.49)$ \\
$\begin{array}{c}12 \text { months } \\
\text { later }\end{array}$ & $\begin{array}{c}\text { turn (sec) } \\
\text { Turn-switching pause (sec) }\end{array}$ & $.85(.48)$ & $.93(.36)$ \\
\hline
\end{tabular}

Vales are presented as Mean (SD)

CWS = children who stutter; CWNS = children who do not stutter
Appendix 6. 평가 후 12 개월 시점의 요인 간 상관관계 분석

\begin{tabular}{lrrr}
\hline Duration type & Group & ND & AD \\
\hline Children's utterance in a & CWS $(\mathrm{N}=6)$ & .086 & .441 \\
conversational turn & CWNS $(\mathrm{N}=6)$ & -.086 & .000 \\
Children's turn-switching pause & CWS $(\mathrm{N}=6)$ & .257 & -.677 \\
& CWNS $(\mathrm{N}=6)$ & -.257 & -.319 \\
Mother's utterance in a & CWS $(\mathrm{N}=6)$ & .200 & $-.736^{a}$ \\
conversational turn & CWNS $(\mathrm{N}=6)$ & .543 & .551 \\
Mother's turn-switching pause & CWS $(\mathrm{N}=6)$ & -.086 & -.265 \\
& CWNS $(\mathrm{N}=6)$ & $-.886 *$ & -.464 \\
\hline
\end{tabular}

$\mathrm{ND}=$ normal disfluency; $\mathrm{AD}=$ abnormal disfluency; $C W S=$ children who stutter; $C W N S=$ children who do not stutter

$\star \mathrm{p}<.05$.

${ }^{a}$ Correlation coefficient .70 or more values.

Appendix 5. 평가 시점의 요인 간 상관관계 분석

\begin{tabular}{lrrr}
\hline Duration type & Group & ND & AD \\
\hline Children's utterance in a & CWS $(\mathrm{N}=6)$ & .143 & -.232 \\
$\quad$ conversational turn & CWNS $(\mathrm{N}=6)$ & .559 & $-.899 *$ \\
Children's turn-switching pause & CWS $(\mathrm{N}=6)$ & .029 & $-.754 a$ \\
& CWNS $(\mathrm{N}=6)$ & .265 & -.232 \\
Mother's Utterance in a & CWS $(\mathrm{N}=6)$ & -.086 & $.754^{a}$ \\
conversational turn & CWNS $(\mathrm{N}=6)$ & .441 & .609 \\
Mother's turn-switching pause & CWS $(\mathrm{N}=6)$ & .143 & $-.754^{\text {a }}$ \\
& CWNS $(\mathrm{N}=6)$ & .088 & -.464 \\
\hline
\end{tabular}

$\mathrm{ND}=$ normal disfluency; $\mathrm{AD}=$ abnormal disfluency; $C W S=$ children who stutter; CWNS = children who do not stutter.

$\star p<.05$.

${ }^{a}$ Correlation coefficient .70 or more values. 


\section{국문초록}

학령전 말더듬아동과 아동의 어머니 간 상호작용 종단적 분석: 대화차례 발화 시간과 쉼 시간을 중심으로 곽효정 $\cdot$ 심현섭 1 이수복 ${ }^{2}$

${ }^{1}$ 이화여자대학교 대학원 언어병리학과, ${ }^{2}$ 우송대학교 언어치료청각재활학과

배경 및 목적: 본 연구는 학령전 말더듬아동과 어머니가 일상에서 상호작용할 때 나타나는 아동과 어머니의 대화차례 발화 시간과 대 화차례 심 시간이 아동의 비유창성과 관련이 있는지 살펴보고 일반아동.어머니 집단과 차이가 있는지 살펴보고자 하였다. 방법: 상호 작용 놀이 상황에서 말더듬아동.어머니 집단 6쌍과 일반아동.어머니 집단 6쌍의 발화를 두 차례(평가 시점, 평가 후 12 개월 시점) 수 집하여 아동의 $\mathrm{ND}$ 와 $\mathrm{AD}$ 빈도, 아동과 어머니의 대화차례 발화 시간과 대화차례 심 시간을 분석하였다. 결과: 평가 시점과 평가 후 12 개월 시점에서 말더듬아동 집단과 일반아동 집단 간 그리고 말더듬아동 어머니 집단과 일반아동 어머니 집단 간 대화차례 발화 시간과 대화차례 쉼 시간이 통계적으로 유의한 차이가 없는 것으로 나타났다. 말더듬아동.어머니 집단은 평가 시점에서 아동 $\mathrm{AD}$ 빈도가 어머 니 대화차례 발화 시간과 정적상관관계를 보였고, 말더듬아동 대화차례 심 시간, 어머니 대화차례 심 시간과 부적상관관계를 보였다. 평 가 후 12 개월 시점에서 말더듬아동 $\mathrm{AD}$ 빈도는 어머니 대화차례 발화 시간과 부적상관관계를 보였다. 논의 및 결론: 본 연구는 말더듬 발생 및 지속과 관련 있는 아동과 어머니 간 상호작용 종단적 특성에 대한 정보를 제공하여 말더듬아동·부모의 상호작용 치료를 통해 학령전 아동이 만성적 말더듬으로 발전될 위험성을 감소시키는데 기여하고자 하였다.

핵심어: 학령전 아동, 말더듬, 종단연구, 상호작용, 대화차례 발화 시간, 대화차례 쉼 시간

이 논문은 2018년 대한민국 교육부와 한국연구재단의 지원을 받아 수행된 연구임(NRF-2018S1A5A2A03036976).

본논문은 제1저자(곽효정)의 석사학위논문(2021)을 발췌 및 수정한 것임.

\section{참고문헌}

김영태 (2014). 아동언어장애의 진단 및 치료(2판). 서울: 학지사.

김영태, 신문자 (2004). 우리말 조음·음운평가(U-TAP). 서울: 학지사.

김영태, 홍경훈, 김경희, 장혜성, 이주연 (2009). 수용·표현어휘력검사(REVT). 서울: 서울장애인종합복지관.

김예슬, 심현섭 (2021). 문장 따라말하기에서 말속도, 발화길이 및 통사적 복잡성에 따른 말더듬 아동과 일반아동의 비유창성 비교. 말소리와 음성과 학, 13(1), 53-64.

김윤숙, 신문자 (2016). 부모교육이 학령전기 말더듬 아동의 비유창성 감소에 미치는 효과 특수교육, 15(3), 59-74.

민경주 (2007). 과제에 따른 취학전 말더듬 아동과 일반 아동의 비유창성 가변성 비교. 이화여자대학교 대학원 석사학위 논문.

박영롱, 최소영 (2019). 그룹프로그램을 통한 대화기술 중재가 학령기 언어발달지체 아동의 대화차례 주고받기 및 주제운용 능력에 미치는 효과. 언어 치료연구, 28(2), 115-128.

박혜연, 이수복, 심현섭 (2015). 취학 전 말더듬아동의 회복여부에 따른 의사소통행동 특성. 언어치료연구, 24(4), 237-248.

배희숙 (2021). 언어발달(2판). 서울: 학지사

심현섭, 신문자, 이은주 (2010). 파라다이스-유창성검사II. 서울: 파라다이스 복지재단.

안정현, 신지철, 김향희, 심현섭 (2009). 조음속도와 반응간격 조절에 따른 말더듬 발생비율의 변화. 언어치료연구, 18(4), 123-138.

옥정달, 이규식 (2003). 부모중심 말더듬치료가 아동의 말더듬 개선에 미치는 효과. 특수교육학연구, 38(2), 153-175.

이수복 (2014). 초기 말더듬아동의 회복여부에 따른 치료효과 예측요인에 관한 종단연구. 이화여자대학교 대학원 박사학위논문.

이수복, 곽효정, 윤재민, 신동춘, 심현섭 (2020). 동영상 기반 자동 발화 심층 분석(SUDA) 어플리케이션 개발. 말소리와음성과학, 12(2), 63-72.

이수복, 박혜연, 심현섭 (2019). 말더듬아동 종단연구에 관한 문헌연구. Communication Sciences \& Disorders, 24(2), 490-506. 
이수복, 심현섭 (2015). 초기 말더듬아동의 치료 후 말더듬회복 예측요인에 관한 종단연구: 발화길이를 중심으로. Communication Sciences \& Disorders, 20(2), 189-201.

이수복, 심현섭 (2016). 초기 말더듬아동의 치료효과 예측변인 연구. Communication Sciences \& Disorders, 21(2), 382-396.

이은주, 심현섭 (2007). 취학전 말더듬아동의 기질과 어머니의 기질 및 양육행동 특성. 언어청각장애연구, 12(2), 279-295.

전희정, 이수복 (2016). 취학 전 말더듬 아동의 말더듬 중증도에 따른 발화 형태 별 조음속도 비교. Phonetics \& Speech Sciences, 8(3), 79-90.

최지은, 이윤경 (2013). 학령기 고기능 자폐범주성장애 아동의 대화차례 주고받기 및 주제운용능력. Communication Sciences \& Disorders, 18(1), $12-23$.

허현숙, 이윤경 (2012). 언어학습부진아동의 대화차례 주고받기 및 주제운용 특성. 언어청각장애연구, 17(1), 66-78.

\section{ORCID}

곽효정(제1저자, 대학원생 https://orcid.org/0000-0002-1704-5278); 심현섭(공동 교신저자, 교수 https://orcid.org/0000-0002-4710-3678) 이수복(대표 교신저자, 교수 https://orcid.org/0000-0001-6942-4635) 